\title{
Ex post analysis of engineered tsunami mitigation measures in the town of Dichato, Chile
}

\author{
Maximiliano Oportus ${ }^{1,2} \cdot$ Rodrigo Cienfuegos $^{1,2}$ D $\cdot$ Alejandro Urrutia ${ }^{2}$. \\ Rafael Aránguiz ${ }^{2,3} \cdot$ Patricio A. Catalán ${ }^{2,4,5} \cdot$ Matías A. Hube $^{6}$
}

Received: 22 May 2018 / Accepted: 24 April 2020 / Published online: 11 May 2020

(C) The Author(s) 2020

\begin{abstract}
Due to Chile's notorious and frequent seismic activity, earthquake- and tsunami-related studies have become a priority in the interest of developing effective countermeasures to mitigate their impacts and to improve the country's resilience. Mitigation measures are key to accomplish these objectives. Therefore, this investigation adopts a tsunami damage assessment framework to evaluate the direct benefits of tsunami mitigation works implemented by the Chilean government in the town of Dichato in the aftermath of the 2010 tsunami. We perform an ex post analysis of the potential damage reduction produced by these works studying what would have been the consequences on the built environment if they were in place for the tsunami that hit this area after the Maule earthquake in February 27, 2010. We use state-of-the-art tsunami simulation models at high resolution to assess the reduction in tsunami intensity measures, which serve as input to evaluate the benefit from averted damage against the costs of the mitigation measures. The obtained results show a reduction in the flooded area and a delay in the arrival times for the first smaller tsunami waves, but a negligible damage reduction when confronted to the largest waves. In conclusion, the tsunami mitigation measures would not have been effective to reduce the impact of the tsunami generated by the Maule earthquake in the town of Dichato, but could have had a benefit in retarding the inundation of low-land areas for the first smaller tsunami waves. The latter suggests that these works might be useful to mitigate storm waves or tsunamis of much smaller scales than the one that hit central-south Chile in 2010.
\end{abstract}

Rodrigo Cienfuegos

racienfu@ing.puc.cl

1 Departamento de Ingeniería Hidráulica y Ambiental, Pontificia Universidad Católica de Chile, Santiago, Chile

2 Centro de Investigación para la Gestión Integrada del Riesgo de Desastres (CIGIDEN), ANID/Fondap/15110017, Vicuña Mackena 4860, Santiago, Chile

3 Departamento de Ingeniería Civil, Universidad Católica de la Santísima Concepción, Concepción, Chile

4 Departamento de Obras Civiles, Universidad Técnica Federico Santa María, Valparaíso, Chile

5 Centro Científico Tecnológico de Valparaíso-CCTVal, Universidad Técnica Federico Santa María, Valparaíso, Chile

6 Departamento de Ingeniería Estructural y Geotecnia, Pontificia Universidad Católica de Chile, Santiago, Chile 
Keywords Tsunami $\cdot$ Mitigation measures $\cdot$ Cost-benefit analysis

\section{Introduction}

Chile is a highly seismic country, mainly due to the subduction process of the Nazca Plate underneath the South American plate (Lomnitz 1970; Araya 2007; Fritz et al. 2011; Centro Sismológico Nacional 2013), where the trench is located very close to the coastline. Many megathrust earthquakes have generated tsunamis, with very short arrival times. Over the past 10 years, four large-magnitude events $(\mathrm{Mw}>7.5)$ have occurred in the country, which generated tsunamis with varying levels of destructiveness. These include the Mw 8.8 Maule earthquake (Fritz et al. 2011) in 2010, the Mw 8.2 Pisagua earthquake (Catalán et al. 2015) in 2014, the Mw 8.3 Illapel earthquake (Aránguiz et al. 2016) in 2015, and the Mw 7.6 Melinka earthquake (Xu 2017) in 2016. The 2010 event caused large-scale economical, structural, and human impacts in central and southern Chile (Gobierno Regional del Bío-Bío 2010; Fritz et al. 2011). This event also triggered an increase in basic and applied research in the country. In addition, the Chilean government invested in several tsunami mitigation projects and reconstruction plans (Siembieda et al. 2012; Herrmann Lunecke 2015; Khew et al. 2015), including hard structures.

Among the most damaged coastal towns in 2010 was Dichato, a relatively small settlement with three thousand inhabitants (according to the last census) (Koshimura et al. 2010), located north of the epicenter, that suffered the destruction of houses and infrastructures near the beach and estuary (Koshimura et al. 2010; Yamazaki et al. 2010; Martínez et al. 2016). After the event, the government proposed a tsunami mitigation plan, which included hard structural countermeasures to reduce the impact of tsunamis. The setting of this new infrastructure provides the opportunity to compare the effect of the tsunami with and without the presence of such mitigation works.

The significant impacts associated with recent tsunamigenic events worldwide have motivated the development of numerous studies devoted to hazard assessment and tsunami modeling (e.g., Arcas and Titov 2006; González et al. 2009; Montenegro-Romero and Peña-Cortés 2010; Nandasena et al. 2012; Imamura et al. 2012; Suppasri et al. 2013; Melgar and Bock 2013; Adriano et al. 2014, 2016; Ozer Sozdinler et al. 2015; Catalán et al. 2015; Goda et al. 2015; Park and Cox 2016; Santa María et al. 2016; Aránguiz et al. 2016; Martínez et al. 2016). For example, the Great Eastern Japan Earthquake and tsunami offered the opportunity to evaluate different types of mitigation measures. Nandasena et al. (2012) made an ex post assessment of the effectiveness of tsunami mitigation works, including vegetated dunes, coastal forest, and seawalls. These are tested using numerical modeling to determine how they influence inundation extent, and other hydrodynamic properties such as momentum flux and velocities (Nandasena et al. 2012). Adriano et al. (2016) evaluated the effect of breakwaters in the coast through similar tsunami modeling approaches, concluding that the breakwater present in Onagawa at the time of the tsunami attack reduced the tsunami impact by diminishing the maximum inundation depth in $2 \mathrm{~m}$, even if it was completely destroyed by the flow (Adriano et al. 2016). The performance of a breakwater located in Kamaishi is assessed by Ozer Sozdinler et al. (2015), who state that even though the presence of a breakwater may generate higher flow velocities, these hard countermeasures were beneficial in decreasing inundation depths and retarding the arrival of peak tsunami inundation. Moreover, it was found that a damaged breakwater could still provide some degree of protection. 
In Chile, no studies on the effectiveness of tsunami mitigation works have been published to date, but some efforts have produced data and relevant information that are worth mentioning. Santa María et al. (2016) produced an exposure model for residential structures that classifies them by characteristics such as construction materials, geo-localization and estimated replacement costs. Martínez et al. (2016) presented an assessment of the vulnerability of Dichato considering physical, socioeconomic, and educational dimensions, comparing pre- and post-event conditions. It is claimed that vulnerability remains large in this town, despite the existence of new tsunami mitigation measures.

In the present work, we aim to assess the benefits that the presence of new mitigation works in Dichato may have generated, if they had been present during the tsunami of February 27, 2010. To this end, we implement a methodology to estimate the direct damage from the tsunami inundation and compare its results with and without the new infrastructure in place. The methodology used is intended to provide ex post evaluation, for the first time in Chile, on the tsunami impact reduction that such works may produce.

The manuscript is organized as follows: Sect. 2 shows a brief overview of the important definitions and concepts being considered here, along with a characterization of the case under study. Section 3 describes the methodology, while in Sects. 4 and 5, we present the main results of the study and a discussion on their potential implications. The conclusions are summarized in Sect. 6.

\section{Background}

\subsection{Definitions}

\subsubsection{Risk, hazard, exposure, and vulnerability}

In what follows, risk is considered to be composed of three factors: hazard, exposure, and vulnerability (Weichselgartner 2001; González et al. 2009; Venegas San Martín 2012). The hazard is quantified by intensity variables that reflect the capability of a certain geophysical phenomenon to inflict harm (González et al. 2009). While in the risk analysis framework it is necessary to assess all the possible events that may occur in the area of interest to yield a probabilistic hazard assessment (Cutter et al. 2000; Pelling et al. 2004), here we limit ourselves to a scenario-based analysis using the actual 2010 tsunami, following similar lines as Suppasri et al. (2013).

The characterization of exposure requires an inventory of all the elements that could be affected by the hazard, such as communities and physical infrastructure (Pelling et al. 2004), identifying those located in the flooded area by the tsunami (PenningRowsell et al. 2005). Lastly, in the context of this study, vulnerability is accounted for structural elements only (i.e., buildings), by means of fragility curves which allow to link hazard intensity variables with the damage probability. Linking hazard, exposure, and vulnerability provides means of assessing the risk level and gives the opportunity to quantify damage reductions from the benefits associated with mitigation measures (e.g., urban planning and relocation, engineered mitigation measures, educational programs, etc.). 


\subsubsection{Estimation of the benefit from averted damage}

The damage reduction of the mitigation works in Dichato can be quantified using a cost-benefit analysis that considers the investment of such works and the benefits they produce against a tsunami. It must be noted that these benefits are exclusively evaluated over direct damage assessment, as other less tangible benefits are beyond the scope of this research. The benefit of the project (B) is estimated as (Ministerio de Desarrollo Social 2013):

$$
B=\int_{0}^{\infty} P(i) \times\left[C_{\mathrm{NP}}(i)-C_{\mathrm{WP}}(i)\right] \mathrm{d} i,
$$

where $P(i)$ is the probability of occurrence of the event $i, C_{\mathrm{NP}}$ refers to the costs with no project in event $i$, and $C_{\mathrm{WP}}$ are the costs with project in event $i$. Since a scenario-based analysis is used in this study, the consideration of the probability of its occurrence is beyond the scope of the investigation. Therefore, Eq. (1) will be adapted, as explained in Sect. 3.2.3.

\subsubsection{Estimation of damage}

A tsunami fragility function or fragility curve constitutes a direct relation between a hydrodynamic feature of the tsunami flow and the probability of damage of a structure (Koshimura et al. 2009a, b; Mas et al. 2012; Suppasri et al. 2012; Adriano et al. 2014; Favier et al. 2014a; Urra Espinoza 2015). They are usually built empirically from different data sources (Koshimura et al. 2009a). As a result, the level of refinement in the data and its categorization (such as construction material and number of stories of the structure) may affect the outcome of the analysis (Goda et al. 2015). Despite this potential shortcoming, fragility functions are essential in the methodology to estimate tsunami damage. The characteristics of the ones used here are described in Sect. 3.2.3.

\subsection{Description of Dichato and the local impact of the 2010 tsunami}

Dichato is located at the south end of the Coliumo Bay, almost $40 \mathrm{~km}$ north of Concepción (see Fig. 1). It consists of over 3000 inhabitants according to the last official census in 2002 (Instituto Nacional de Estadísticas) and about 2000 homes. The most common construction materials of buildings are wood and masonry (Servicio de Impuestos Internos). The Coliumo Bay has low wave energy, owing to the protection provided by the Tumbes Peninsula to SW incoming waves. On the other hand, its horseshoe shape may induce long wave resonance (Gobierno Regional del Bío-Bío 2010). The 2.4-km-long beach of Dichato makes the area a touristic attraction, especially during summer, when the population can increase up to 5000 inhabitants (Koshimura et al. 2010; Venegas San Martín 2012).

At 3:34 a.m. (local time) in February 27, 2010, a violent earthquake shook the central region of Chile. The epicenter was located off the Chilean coast, about $105 \mathrm{~km}$ northeast from the city of Concepción (Saito et al. 2010; Yamazaki et al. 2010) with a reported moment magnitude (Mw) of 8.8 (Pulido et al. 2010; Saito et al. 2010; Mas et al. 2012; Robertson et al. 2012). The tsunami generated free surface disturbances observed all around the Pacific Ocean basin, including the coast of Japan (Koshimura et al. 2010; Robertson et al. 2012). Five hundred and twenty-one people died as a direct result of either 


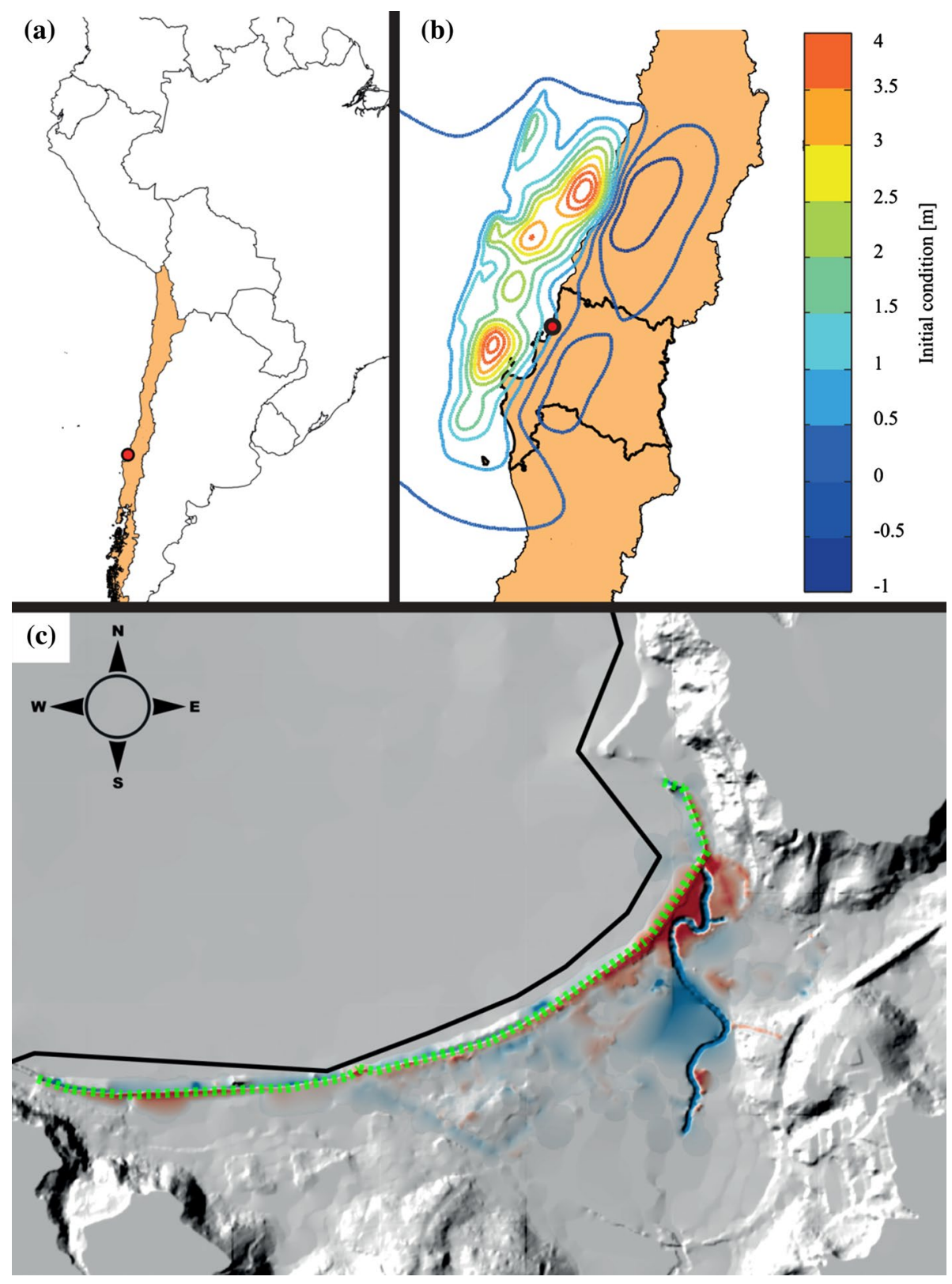

Fig. 1 a Location of the town of Dichato in Chile. b Coseismic vertical displacement produced by the Maule earthquake computed from Delouis et al. (2010) seismic source. c Topography of Dichato: the regions in red are higher in the new scenario compared to the base scenario, and regions in blue are lower. The green line represents the layout of the seawall constructed after the tsunami

the earthquake or tsunami. The tsunami itself claimed 124 victims and 46 missing, mainly in the coastal regions between latitudes $34.5^{\circ}$ and $38^{\circ}$ south (Nahuelpan López and Varas Insunza 2010; Fritz et al. 2011). Nearly 370,000 homes were damaged and the economic 
loss was estimated in USD 30 billion, which was roughly $15 \%$ of Chile's gross domestic product in 2010 (Yamazaki et al. 2010).

Dichato was one of the most affected locations. Inundation depths in Dichato were estimated by post-tsunami surveys to be around $8 \mathrm{~m}$, and water penetrated as far as $1.3 \mathrm{~km}$ inland (Martínez et al. 2016). Though most people were able to evacuate, there were 66 fatalities in Dichato, mostly tourists and elders who underestimated the intensity of the phenomenon (Mas et al. 2012). More than 1200 families reported damages to their properties (Koshimura et al. 2010), and approximately $80 \%$ of the exposed built structures were washed away (Gobierno Regional del Bío-Bío 2010), evidencing the high degree of destruction from the tsunami (Venegas San Martín 2012; Martínez et al. 2016). This level of damage can be explained by the existence of wood houses, which were unable to uphold the large inundation depths and velocities. Damage was also induced by floating debris, including loose boats that collided against structures.

\subsection{Mitigation works and relocation}

Due to the tsunami impact in 2010, the Chilean government financed a mitigation project aimed to provide protection for Dichato and the community against future tsunamis (Martínez et al. 2016). This mitigation project consists of a low-height seawall approximately $4 \mathrm{~m}$ tall and $1.7 \mathrm{~km}$ long, made of reinforced concrete along the coastline, and a channeling of the Dichato Estuary at its mouth (see Fig. 1c). With the information provided by the Division of Port Infrastructure of the Minister of Public Works (Dirección de Obras Portuarias-DOP) and reference prices from a catalogue (Portal Ondac Construcción), the estimated construction costs of the wall and channel are US\$ 6.8 million (details of this estimation are given in "Appendix 1," Fig. 8 and Tables 4, 5, 6, 7, 8). On the other hand, five neighborhoods were relocated either to higher areas or to piloted houses north of the Bay. Building restrictions were established in the town, allowing only commerce-related infrastructure along the coastline of the town. In this area, there is also a mitigation park, consisting of trees planted along the coastline, but its construction only started in 2015 (Martínez et al. 2016).

\section{Methodology}

The tsunami hazard associated with the 2010 tsunami is estimated by means of numerical modeling. Exposure is assessed from building inventories, and the vulnerability is estimated through fragility curves.

The benefit of tsunami damage reduction from engineered mitigation measures on the coastal urban area is evaluated by a cost-benefit analysis of direct costs associated with the inflicted damage to buildings by the tsunami, and the investment costs for the mitigation measures. Hence, by taking the difference between results considering the situation with and without mitigation works, we can estimate the potential improvement that the project would have produced. We are not attempting to give a comprehensive economic evaluation of the future benefits, but to provide a quantification of the potential improvement that this works could produce if the town was subjected to a similar event on a ceteris paribus framework. 


\subsection{Tsunami modeling}

We employ the open source code GeoClaw to perform the tsunami modeling. GeoClaw solves the nonlinear shallow water equations using finite volume methods and adaptive mesh refinement. The code has been used to model several historical tsunamis using bathymetric and topographic data (MacInnes et al. 2013; Melgar and Bock 2013; Arcos and LeVeque 2015). Tsunami waves along the coast of Chile have been known to last several hours (Catalán et al. 2015), including the 2010 event (Venegas San Martín 2012); hence, the simulation time is set to $8 \mathrm{~h}$, which is considered sufficient to model the largest latearriving waves (Yamazaki and Cheung 2011).

The information available did not allow us to include buildings in the topography, so a spatially constant Manning roughness coefficient of $0.2 \mathrm{~s} / \mathrm{m}^{1 / 3}$ is considered, as it produces the best agreement with in situ measurements (see Sect. 4.1). The spatial grid for the tsunami simulation is composed of eight rectangular nested grids, with a threefold increase in resolution between each one. The smallest computational grid, enclosing the Coliumo Bay, is built from bathymetric data collected before the event (2009) and has a resolution of 2 $\mathrm{m}$ (see Fig. 1c), while the spatial discretization in the largest grid is $1 \mathrm{~km}$. The time steps in the simulations are adjusted dynamically to enforce the fulfillment of the Courant-Friedrichs-Lewy (CFL) stability conditions. The reference level used for the bathymetry and topography was the mean sea level, corrected by the tide level at the time of the event.

To incorporate the mitigation measures in the tsunami modeling, an in situ campaign was carried out to obtain the updated topography with high resolution (wall, park, channels) using differential GPS. Data were corrected by means of the Ntrip network. As a result, the topography for the tsunami simulation considered the aggregate of the data collected before and after the event. The difference between the digital elevation model (DEM) including mitigation works and the original can be appreciated in Fig. 1c. The most important changes are around the wall and along the estuary.

The finite fault seismic source model proposed by Delouis et al. (2010) is used and validated. The initial condition of the displacement of the ocean's free surface is obtained from the Okada formulation (Okada 1985). Figure 1b shows this displacement surface where it can be seen that Dichato is located slightly north of one of the two maxima.

\subsection{Damage estimation}

\subsubsection{Exposed buildings}

The exposed residential buildings in Dichato and the tsunami effect on them are considered in this study. For simplicity, only the physical damage induced by the tsunami waves to these buildings is considered. The social impacts or other economic losses are beyond the scope of this work because of the difficulty in quantifying their vulnerability, especially when it comes to social vulnerability (Cutter et al. 2003). The characteristics of houses, construction materials, price values, and year of construction were estimated from a database provided by the Revenue Service (Servicio de Impuestos Internos). This database consists of 1878 houses; however, during the fieldwork, only 452 of them could be properly identified and geo-localized of the database. Hence, we use herein only the identified buildings which are considered as a sample of nearly $40 \%$ of the houses directly exposed to the tsunami waves. The characteristics and the spatial distribution of the inventory can be 


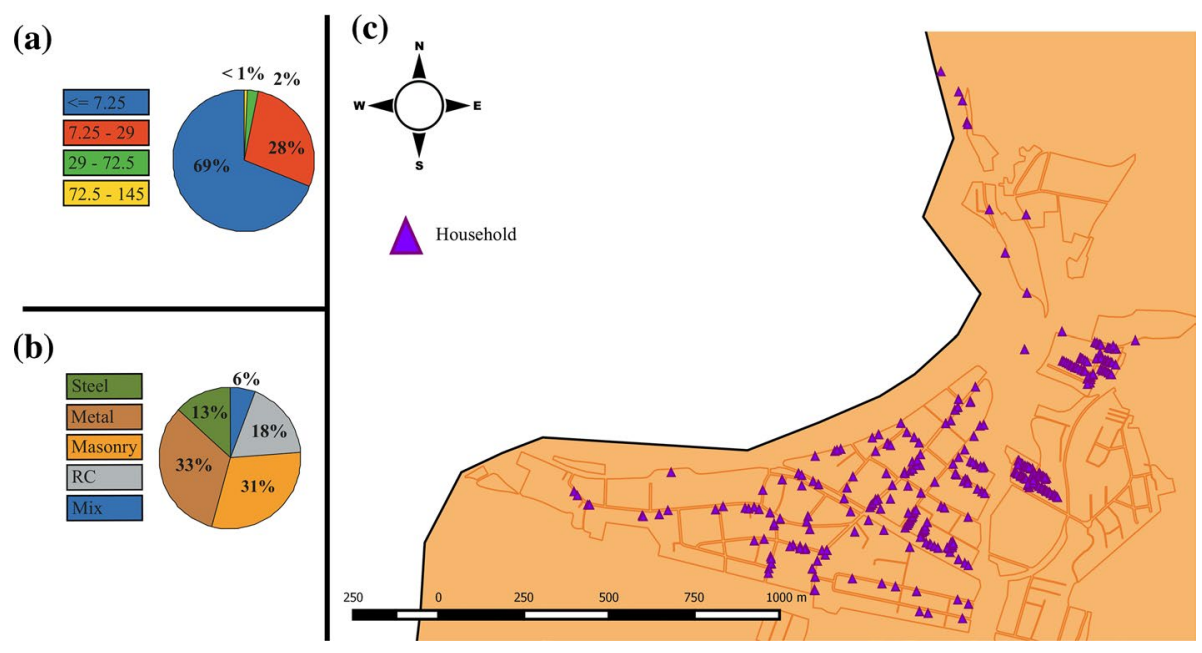

Fig. 2 Inventory of houses in Dichato. a Price distribution (in thousands USD) of the household sample, b materiality distribution of the household sample, and c spatial distribution of the sample of houses in Dichato, where colored triangles represent the individual households

seen in Fig. 2. Most of the houses in Dichato are built with wood and masonry, while the rest are built with concrete, steel or other less common materials (see Fig. 2b). On the other hand, the majority of houses were valued in approximately US\$7000 (Servicio de Impuestos Internos) (see Fig. 2a).

\subsubsection{Tsunami intensity measures}

The hazard intensity is estimated by computing inundation depths, velocity, energy, and arrival times (Macabuag et al. 2016; Park and Cox 2016). Maximum inundation depths are considered as the most relevant parameter because when used in conjunction with fragility curves, they allow to evaluate the probability of damage of individual buildings (Cançado et al. 2008). Nevertheless, the other intensity measures are also of interest. Flow velocities, for instance, have been studied and utilized for the development of fragility curves for structural damage in buildings (Mas et al. 2012; Park and Cox 2016; De Risi et al. 2017), as they may contribute with information about the interactions between the flow and the topography that otherwise cannot be attained (Suppasri et al. 2012; Arcos and LeVeque 2015). In addition, both maximum inundation depths and velocities have been found to be applicable for the estimation of building damage due to tsunamis (Park and Cox 2016). Thus, maximum flow velocities and maximum energy — as an extension of the latter-are also estimated from the tsunami simulation as reference.

\subsubsection{Damage estimation}

Fragility curves are used to estimate the probability of damage generated by the tsunami to the physical infrastructures. Direct damage is thus considered to be the result of the interaction between hydrodynamic forces and the structures (Penning-Rowsell et al. 2005). The damage depends on the construction material of buildings, and several damage levels can be considered. 
Suppasri et al. (2012) performed an analysis of all available data delivered by the Ministry of Land, Infrastructure and Transportation of Japan (MLIT) regarding the 2011 Great East Japan tsunami impact zone. These authors developed fragility curves with six damage levels for wood, masonry, reinforced concrete, and steel frame houses, with the damage levels shown in Table 1 (Suppasri et al. 2012). These fragility curves were chosen since they involved the same four main construction materials observed in Dichato, with the possibility of including different damage levels for each materiality.

Considering that a common type of building in Dichato is best represented as a concrete house in the first story ( $2 \mathrm{~m}$ in height), and as a wooden house in the second story, an additional fragility curve was arranged for the purpose of this investigation, by combining those of wooden and concrete fragility curves. More details are provided in "Appendix 2.1."

With the probability of having the different damage levels for each building, the expected loss is quantified in monetary terms. The cost of repair $\left(C_{r}\right)$ is assumed to be a percentage of the construction cost $\left(C_{t}\right)$, as the more expensive the construction cost of a house would mean a more costly reparation as well. Likewise, if a building is constructed with cheap materials, the costs of repairing are assumed to be low. The relation between the two costs is a function of the damage level, which determines how much of the total construction cost the repairing cost is. Table 1 shows this relation. For example, if the building suffers minor damage, the repair cost is a fraction of the construction cost, assumed as $C_{r}=0.2 C_{t}$. If the house is washed away, the repair cost is larger than the construction cost $\left(C_{r}=1.2 C_{t}\right)$. This estimated larger cost is attributed to the management and disposal of debris.

Finally, the total costs from the loss induced by the tsunami for each scenario are estimated as the aggregate of costs from all buildings. This is simply the sum of the product between the cost ratios and their probability of occurrence for every damage level and every type of material, i.e.,

$$
C=\sum_{k} \sum_{i} P\left(d s_{i}\right) \times c_{i}
$$

where $d s_{i}$ stands for damage state $i, c_{i}$ for the corresponding cost ratio $\mathrm{Cr} / \mathrm{Ct}$ for the damage state $i$, and $P\left(d s_{i}\right)$ for the probability of damage for damage state $i$. Finally, the expected damage $\sum_{i} P\left(d s_{i}\right) * c_{i}$ for each building $k$ is summed up to give the total expected damage.

The cost-benefit analysis considers the comparison between costs that are averted by the application of mitigation measures and those without mitigation (Penning-Rowsell et al. 2005; Ministerio de Desarrollo Social 2013; Iwata et al. 2014). Equation (1) is adapted to take into consideration only one realization:

Table 1 Costs of repair associated with each level of damage

\begin{tabular}{lll}
\hline Damage level & Description & $\begin{array}{l}\text { Cost of } \\
\text { repair } \\
\left(C_{r} / C_{t}\right)\end{array}$ \\
\hline 1 & Minor damage & 0.2 \\
2 & Moderate damage & 0.4 \\
3 & Major damage & 0.6 \\
4 & Complete damage & 0.8 \\
5 & Collapse & 1.0 \\
6 & Washed away & 1.2 \\
\hline
\end{tabular}




$$
B=C_{\mathrm{NP}}-C_{\mathrm{WP}}
$$

\section{Results}

\subsection{Tsunami impact without engineered mitigation measures}

First, the tsunami modeling is carried out without mitigation works in order to estimate a reference scenario, and to validate the model. For the latter, results are compared to field data from in situ surveys summarizing observations from five campaigns, resulting in a set of 37 measurements (Imamura et al. 2010; Matsutomi et al. 2010; Fritz et al. 2011; Mikami et al. 2011).

To estimate the tsunami model performance, Aida's root-mean-square error (RMSE) method is used (Aida 1978), as done by Shuto (1991), Koshimura et al. (2009b), Suppasri et al. (2012), and Martínez et al. (2016). Parameters $K$ and $\kappa$ are presented in Eqs. (4) and (5), respectively, where $K_{i}$ stands for the ratio between observed and simulated values of inundation height.

$$
\begin{gathered}
\log K=\frac{1}{n} \sum_{i=1}^{n} \log K_{i} \\
\log \kappa=\sqrt{\frac{1}{n} \sum_{i=1}^{n}\left(\log K_{i}\right)^{2}-(\log K)^{2}}
\end{gathered}
$$

In 2002, the Japan Society of Civil Engineers (JSCE) proposed that $K$ and $\kappa$ values in the range $0.95<K<1.05$ and $\kappa<1.45$ indicate a good estimation (Tsunami Evaluation Subcommittee and Nuclear Civil Engineering Committee 2002).

The observed and numerical sets of inundation heights are used to evaluate the $K_{i}$ coefficients from five post-tsunami surveys, resulting in a set of 37 observations (Imamura et al. 2010; Matsutomi et al. 2010; Fritz et al. 2011; Mikami et al. 2011). These 37 measurements are then compared with simulated data to obtain $K_{i}$, and by the use of Eqs. (4) and (5), the values of the parameter $K$ and $\kappa$ are found. The Dichato simulation yields $K=0.97$ and $\kappa=1.38$, which is within the recommended limits.

The tsunami simulation results are also qualitatively compared with inundation maps obtained by Mas et al. (2012) (Fig. 3a). Relative sea levels during the event are compared with the information registered at the Talcahuano port inside the Bay of Concepción, as seen in Fig. $3 b$ and with data provided by a Deep-ocean Assessment and Reporting of Tsunamis (DART) Station off the coast of northern Chile and southern Peru (Fig. 3c).

Peak values of inundation depths, flow velocities, energy, and arrival times estimated with the tsunami model are shown in Fig. 4. The highest inundation depth was nearly $10.8 \mathrm{~m}$. The maximum run-up reached $16 \mathrm{~m}$. For flow velocities, the maximum value, as shown in Fig. 4b, is nearly $11.4 \mathrm{~m} / \mathrm{s}$. Local energy values are calculated using Bernoulli's expression $H=h+\frac{v^{2}}{2 g}$, where $h$ stands for inundation depth, $v$ for flow depth-averaged velocity, $g$ for the gravitational acceleration, and $H$ for the hydraulic head. The results obtained for maximum energy are shown in Fig. 4c. Figure 4d also shows that 
(a)

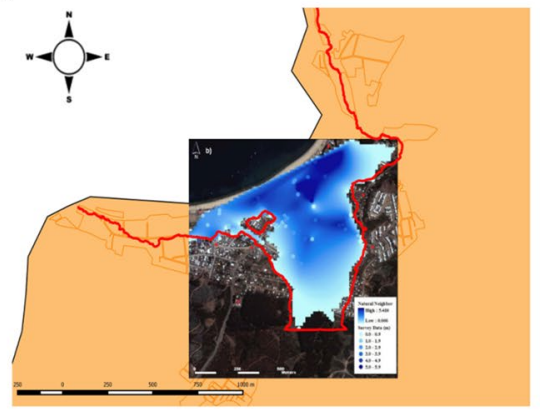

(c)

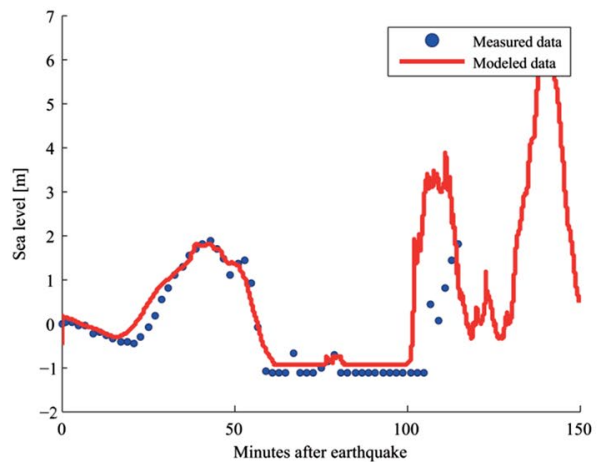

(b)

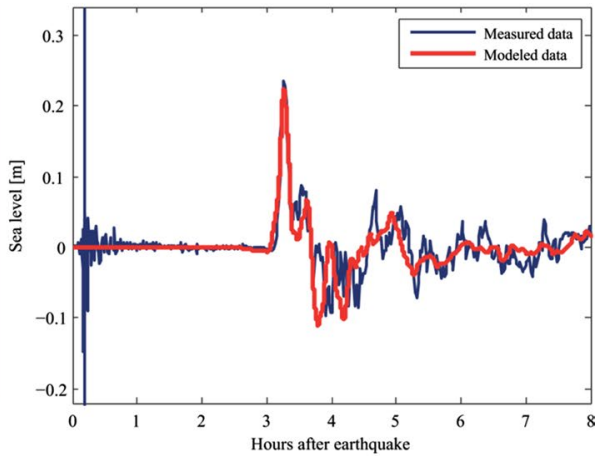

(d)

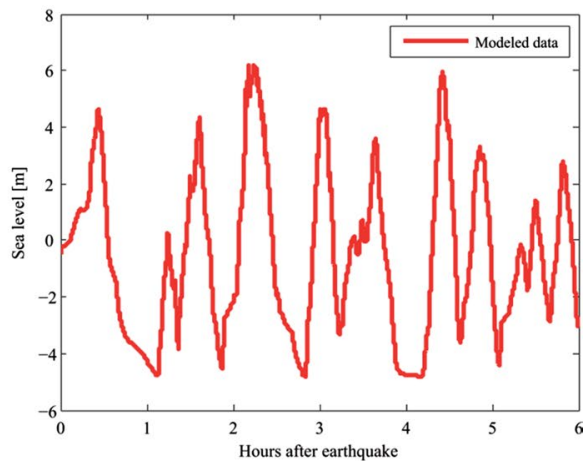

Fig. 3 a Comparison of the modeled maximum inundation (in red) with the post-tsunami survey from Mas et al. (2012). b Modeled (red) and measured (blue) sea level variations at DART buoy $32,412\left(17^{\circ} 59^{\prime} 1^{\prime \prime} \mathrm{S}\right.$ $86^{\circ} 22^{\prime} 28^{\prime \prime} \mathrm{W}$ ). c Modeled (red) and measured (dotted blue) see surface evolution at the Talcahuano tidal gage. d Modeled time series in the bay of Dichato

there is an inundation of low areas within $50 \mathrm{~min}$, but that the larger inundation extent occurs after $100 \mathrm{~min}$. The total costs for this scenario are of nearly USD \$ 2.9 million.

\subsection{Tsunami impact considering the engineered mitigation measures in place}

Next, simulations including the mitigation works are carried out considering the updated topography. Figure 5 shows the differences between this modified scenario and the baseline scenario. Negative values denote the baseline scenario values exceed those of the modified case. Values for inundation depths and run-ups with the incorporation of mitigation works have maxima of $10.6 \mathrm{~m}$ and $16 \mathrm{~m}$, respectively, which are very similar to the base scenario. Near the estuary, depths are larger owing to the channeling effect of the works. However, for the maximum hydraulic head, the modeled values in the modified situation are lower than the baseline scenario, which highlights the potential in reducing the energy of the flow. The total costs estimated for the direct damage in this case are \$USD 2.7 million.

A summary of these results is presented in Table 2. 
(a)

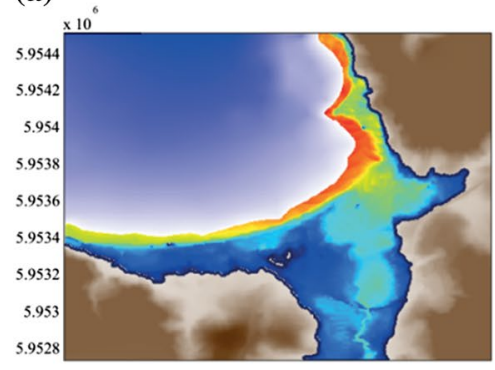

(c) $\times 10^{\circ}$
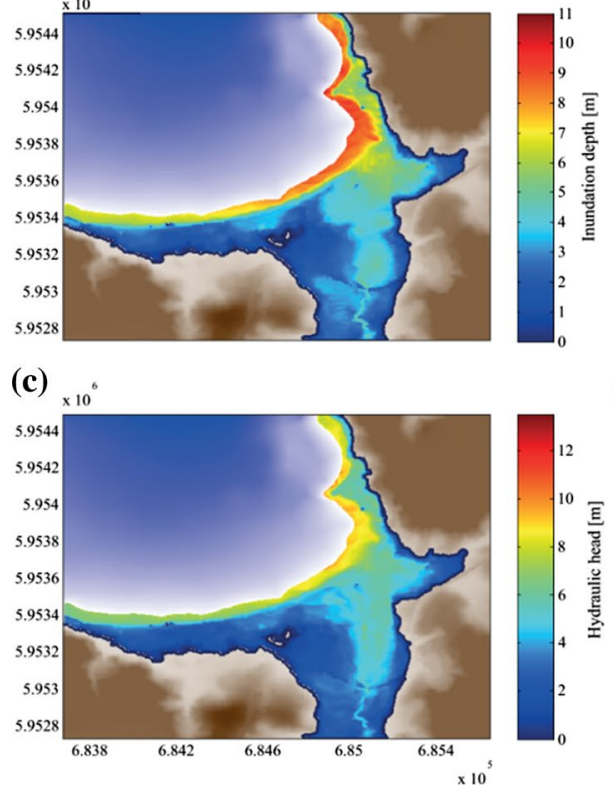

(b)

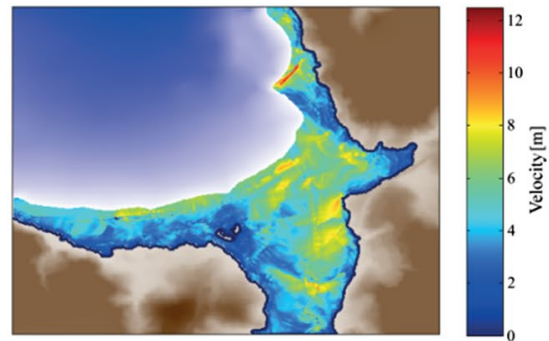

(d)

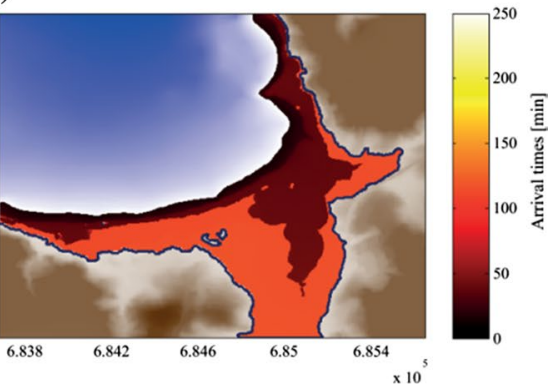

Fig. 4 Results of the simulation on Dichato's base scenario. The maximum values of a inundation depths, $\mathbf{b}$ flow velocities, $\mathbf{c}$ energy, and $\mathbf{d}$ tsunami arrival times

(a)

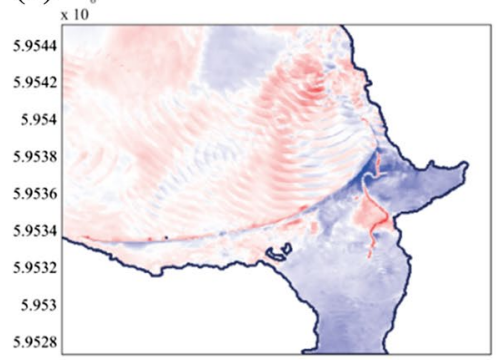

(c)

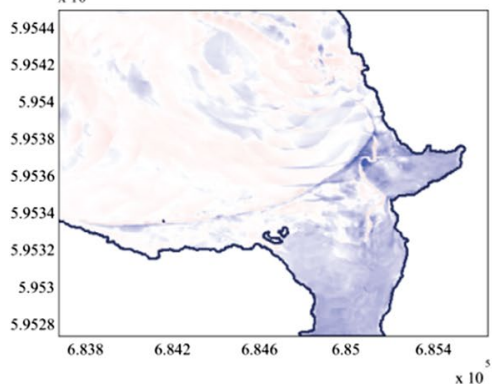

(b)
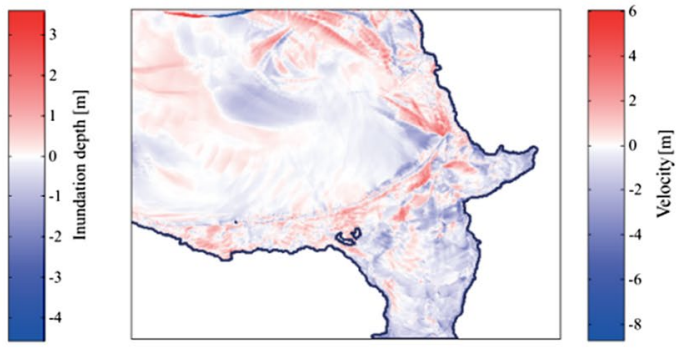

(d)

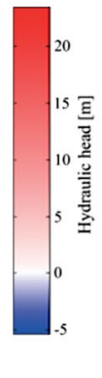

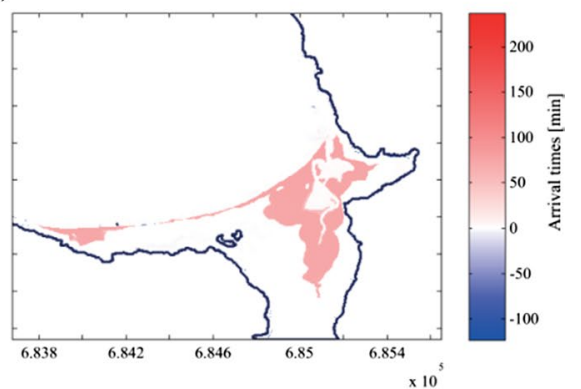

Fig. 5 Results of the simulation on Dichato considering the mitigation measures, in contrast to the base scenario. Red regions correspond to higher values in the new scenario, and blue when values are lower. Difference of maximum a inundation depths, $\mathbf{b}$ velocities, and $\mathbf{c}$ energy. $\mathbf{d}$ Arrival times for the new scenario 
Table 2 Summary of results considering scenarios without and with mitigation works

\begin{tabular}{lll}
\hline & $\begin{array}{l}\text { Inundated area } \\
\left(\mathrm{km}^{2}\right)\end{array}$ & $\begin{array}{l}\text { Damage } \\
\text { costs (MM } \\
\text { USD) }\end{array}$ \\
\hline Without mitigation measures & 13.4 & 2.9 \\
With mitigation measures & 13.2 & 2.7 \\
Direct benefit & & 0.2 \\
\hline
\end{tabular}

Considering inundation depths are similar and that the damage estimation depends directly and solely on this variable, the benefit obtained with the presence of the mitigation works is estimated to be only of USD $\$ 211,000$, i.e., a reduction of $7 \%$.

\section{Discussion}

The Dichato reconstruction plan incorporated hard mitigation measures to minimize future tsunami impacts in the bay, but our results show that when confronted to the 2010 tsunami, the level of direct damage reduction is only marginal. The most relevant mitigation aspect corresponds to a delay in arrival times of tsunami waves, as the inundation area of the second wave is reduced to approximately $40 \%$ in the presence of the seawall and channel. The time available to carry out an evacuation in the area located in the vicinity of the river mouth is thus increased to approximately an hour, as shown in Fig. 5d. This aspect is relevant for evacuation purposes, but it is a benefit that is not granted for other tsunamis since it is highly dependent on the characteristics of the seismic source; indeed for the 2010 tsunami, the largest tsunami waves that arrived to Dichato were not the first to come, but this situation could be different for other events. Indeed, the largest wave arrived $120 \mathrm{~min}$ after the earthquake in 2010 and inundated roughly the same area as it did in the case we simulated with the engineered structures in place. Hence, the conducted mitigation works might be efficient against more frequent and less destructive events, such as storm waves or surges or even minor tsunamis, but are not able to withstand the largest tsunami waves generated by an event similar to the one that occurred in 2010 .

This finding motivates us to evaluate alternatives for the wall height and to produce a sensitivity analysis on this design parameter. The rationale behind this analysis is that one would expect that a higher wall height should produce larger direct benefits than the costs of construction, and eventually, and optimum constrained to specific objectives or criteria could be found. Thus, we consider different wall heights from $+0.5 \mathrm{~m}$ up to $+4 \mathrm{~m}$ from its actual configuration, to assess potential mitigation effects and damage reductions in view of determining an optimal wall height (Favier et al. 2014b; Shimozono and Sato 2016).

We thus perform additional tsunami simulations and re-assess the cost-benefit analysis considering walls $0.5,1.0,2.0,3.0$, and $4.0 \mathrm{~m}$ taller than the actual one of $5 \mathrm{~m}$ on average. Special structural designs or protection elements that would increase the construction costs of higher walls to ensure its correct performance in this situation are not included, since the costs are only assumed to be proportional to the height of the wall. It is also important to emphasize that a more comprehensive analysis would require the inclusion of a time window for life operation of the engineered works, the probability of exceedance of certain tsunami hazard level each year, and a cash flow for costs and benefits. Although difficult to quantify, these indirect impacts are also important and should be considered in the design and decision process. 
The resulting inundation maps for the same 2010 event are shown in Fig. 6. As expected, as the wall height increases, the inundated area gradually decreases and the damage cost reduction increases, as summarized in Table 3. Indeed, when the height of the seawall is increased in $3 \mathrm{~m}$, the flooded area is greatly reduced (43.3\% of area reduction and an $88.9 \%$ reduction in damage costs). The different scenarios are summarized

(a)

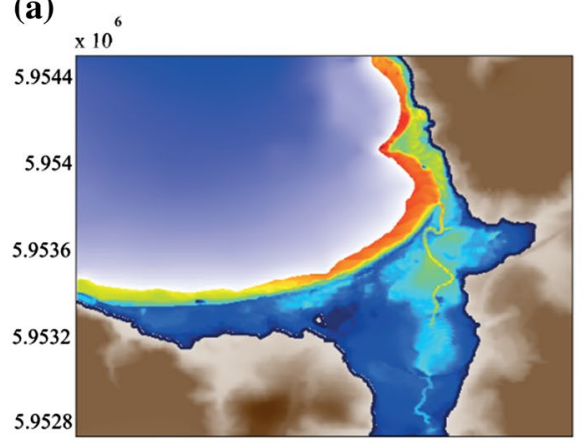

(c) $\times 10^{6}$

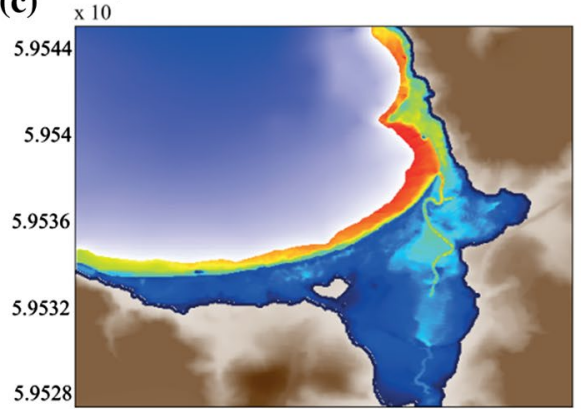

(e) $\times 10^{6}$

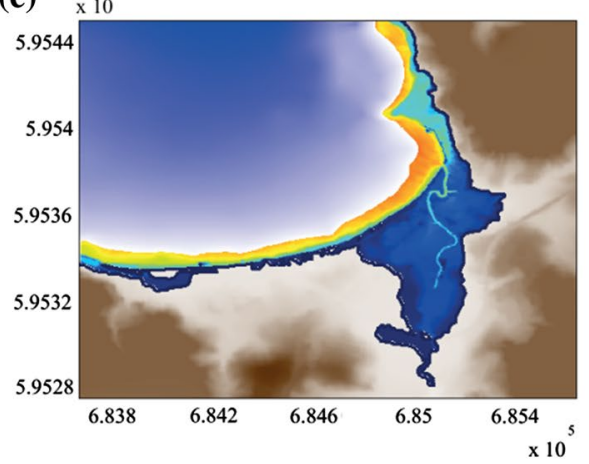

(b)

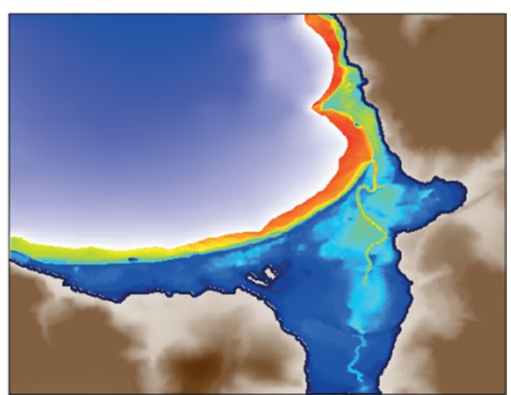

(d)

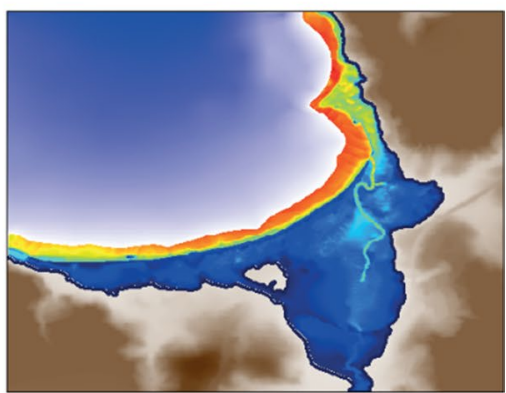

(f)

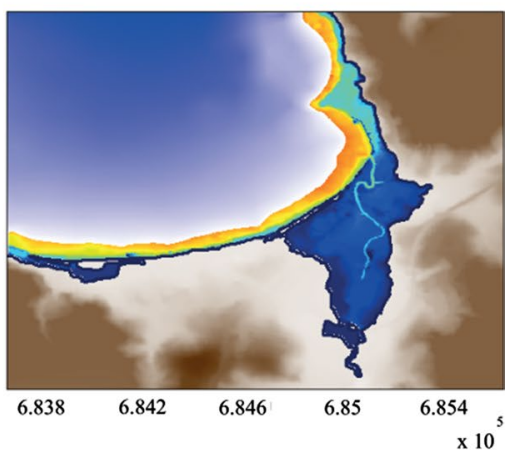

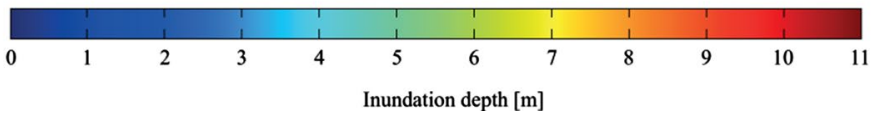

Fig. 6 Results of the simulation on Dichato considering different wall heights. The maximum values of inundation depths for the a scenario with the existent mitigation works, b with a wall $0.5 \mathrm{~m}$ taller, $\mathbf{c} 1 \mathrm{~m}$ taller, $\mathbf{d} 2 \mathrm{~m}$, e $3 \mathrm{~m}$ taller, and $\mathbf{f} 4 \mathrm{~m}$ taller 
Table 3 Reductions with respect to the base scenario when increasing the height of the seawall

\begin{tabular}{lllll}
\hline $\begin{array}{l}\text { Increase in wall } \\
\text { height }(\mathrm{m})\end{array}$ & $\begin{array}{l}\text { Inundated area } \\
\left(\mathrm{km}^{2}\right)\end{array}$ & $\begin{array}{l}\text { Area reduction } \\
(\%)\end{array}$ & $\begin{array}{l}\text { Damage costs } \\
(\text { MM USD) }\end{array}$ & $\begin{array}{l}\text { Damage reduction with } \\
\text { respect to the base scenario } \\
(\%)\end{array}$ \\
\hline+0.5 & 13.0 & 3.0 & 2.8 & 4.5 \\
+1 & 12.6 & 6.0 & 2.4 & 16.7 \\
+2 & 11.7 & 12.7 & 1.9 & 34.9 \\
+3 & 7.6 & 43.3 & 0.3 & 88.9 \\
+4 & 7.2 & 45.6 & 0.3 & 90.1 \\
\hline
\end{tabular}

Fig. 7 Benefits versus construction costs for different wall height scenarios

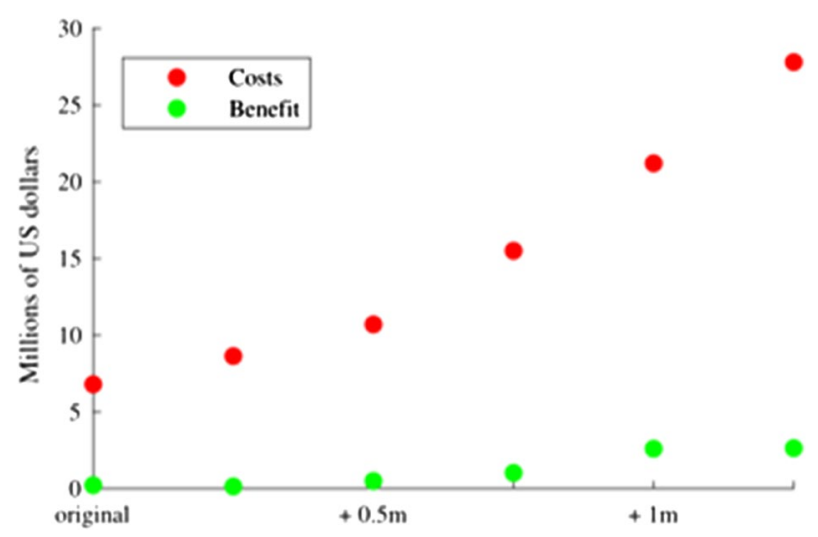

in Fig. 7, where it can be seen that the application of the methodology brings valuable technical information for decision making; nonetheless, this dimension constitutes only one element among many others that come into play before deciding investing in mitigation works. Indeed, the final decision has more to do with political issues, as it seems to have been the case in Dichato since we could not find any technical justification for the selected wall height in the official documents we could gather.

In addition to hard mitigation structures, which are not foolproof, other measures can also be considered. With this regard, sustaining education and awareness programs to ensure an effective evacuation response in case of a disaster should not be undermined (Favier et al. 2014b). Mitigation and risk communication strategies unbalanced toward hard measures may induce a false sense of security (Suppasri et al. 2013).

Urban planning is another important risk reduction tool that can be informed by the type hazard and damage assessment analysis presented here. The latter could be useful to improve the preparedness of Dichato against an event similar to the one that hit Chile in 2010. For example, if additional studies of potential evacuation are considered, restriction areas based on this information could be defined to ensure a prompt and safe evacuation (e.g., Imamura et al. 2012; León et al. 2019).

\section{Conclusion}

The present investigation provides an ex post analysis of the effectiveness of the mitigation measures that were built in the town of Dichato in the aftermath of the 2010 tsunami. This is the first study of this kind in Chile, but follows similar lines than research 
published after the 2011 Tohoku tsunami in Japan. Our results suggest that the seawall and the channeling of the river account for a direct damage cost reduction of nearly $7 \%$ if faced to a similar tsunami than the one that hit this town in 2010 , with an estimated cost of implementation of USD $\$ 6.8$ million. However, damage reduction could be increased if taller walls were considered, as a reduction of over $85 \%$ in damage costs is estimated with a wall $3 \mathrm{~m}$ taller than the reference one. Indeed, the direct benefits of the current measures are minor (approximately 200 thousand US dollars) and would deserve to be confronted with other indirect costs which should also include the impact on tourism and beach erosion over the operation lifetime of the mitigation works.

The most important effect of the conducted mitigation works is an increase in evacuation times for the area close to the river, which should bring additional indirect benefits that are not accounted for in the present study. The latter is explained by the particularities of the tsunami hydrodynamics at this location since the biggest wave is not much affected by the mitigation works, and it arrives $2 \mathrm{~h}$ after the nucleation of the earthquake. This can be a situation particular to this place and event, so these results should be treated as a first estimate of the benefit.

Despite this potential shortcoming, our simulations suggest that the mitigation works in place could be effective against minor tsunamis, storm waves or surges, but not against the biggest waves produced by a similar event than the one that occurred in 2010 .

While the present research is important to provide an ex post assessment of the mitigation work effectiveness, a more comprehensive analysis for the definition of optimal measures should consider additional aspects that are not easy to evaluate such as probabilistic simulation of the tsunami hazard, risk perception, and cultural issues. Indeed, mitigation plans should be evaluated from more complex perspectives than direct damage reductions attributed to hard works, including community risk awareness, land use, and evacuation plans.

Acknowledgements This investigation was funded by Centro Nacional de Investigación para la Gestión Integrada de Desastres Naturales (CIGIDEN), ANID/Fondap/15110017 and CONICYT/PIA/Basal/FB0821. The authors extend their thanks to Dr. Paula Aguirre, Evans Aravena, Karla Contreras, Dr. Ian del Río, Juan Carlos Domínguez, Diego Espinoza, Dr. Philomène Favier, Dr. Carolina Martínez, Dr. Erick Mas, Georgette Mell, Dr. Luis Ignacio Rizzi, Andrea Vásquez, and Dr Patricio Winckler who contributed to the investigation and to the whole team led by Dr Rodrigo Cienfuegos.

Open Access This article is licensed under a Creative Commons Attribution 4.0 International License, which permits use, sharing, adaptation, distribution and reproduction in any medium or format, as long as you give appropriate credit to the original author(s) and the source, provide a link to the Creative Commons licence, and indicate if changes were made. The images or other third party material in this article are included in the article's Creative Commons licence, unless indicated otherwise in a credit line to the material. If material is not included in the article's Creative Commons licence and your intended use is not permitted by statutory regulation or exceeds the permitted use, you will need to obtain permission directly from the copyright holder. To view a copy of this licence, visit http://creativecommons.org/licenses/by/4.0/.

\section{Appendix 1: Valuation of mitigation works}

To perform an approximate valuation of the mitigation works, a simplified version of the wall and channels' structures was considered, as composed of fewer materials. This simplification was carried out because of practical matters. All the information used to perform this valuation was provided by the Dirección de Obras Portuarias (DOP) and the Ondac catalogue, and in Table 4 is a detail of the materials considered in both the 
Table 4 Detail of the materials considered for the valuation of the mitigation works

\begin{tabular}{lcc}
\hline Material detail & Unit & Price (USD) \\
\hline Hormigón H-20 (RC) & $\mathrm{m}^{3}$ & 79.78 \\
Hormigón HN-25 (RC) & $\mathrm{m}^{3}$ & 68.87 \\
Hormigón H-30 (RC) & $\mathrm{m}^{3}$ & 97.24 \\
Enfierradura $D=10$ mm a 44-28 (iron) & $\mathrm{kg}$ & 1.18 \\
Relleno con material de obra (filling) & $\mathrm{m}^{3}$ & 5.72 \\
Compactación con rodillo $e=30 \mathrm{~cm}$ (compacting) & $\mathrm{m}^{2}$ & 0.32 \\
Relleno con bolón (filling) & $\mathrm{m}^{3}$ & 31.53 \\
Bombeo de hormigón (RC pumping) & $\mathrm{m}^{3}$ & 13.89 \\
Excavación terreno blando $a=1 \mathrm{mt}$ (excavations) & $\mathrm{m}^{3}$ & 4.52 \\
\hline
\end{tabular}

wall and channel. The prices are according to the Chilean market and include workforce and other minor materials required.

The mitigation works can be better appreciated in Fig. 8.

\section{Appendix 1.1: Wall}

The wall's construction was divided in three sectors, each with a different set of profiles. The profiles each have different sizes and material proportions that define their construction costs, so to obtain the total cost of the wall's construction, it is necessary to calculate the amount of each material required for each profile along every set. Every profile's length together with the materiality information was obtained from a set of drawings provided by the DOP. The following tables specify the amount of each material used per profile and their length for each sector. The excavations along each sector were calculated using a mean area, which in the case of Litril Sector is $22.50 \mathrm{~m}^{2}$, for Etapa 1 Sector is $13.05 \mathrm{~m}^{2}$ and for Estero Sector is $9.88 \mathrm{~m}^{2}$ (Tables 5, 6, 7).

It should be noted that the geometry of every profile was simplified into basic geometric elements, such as squares and triangles.

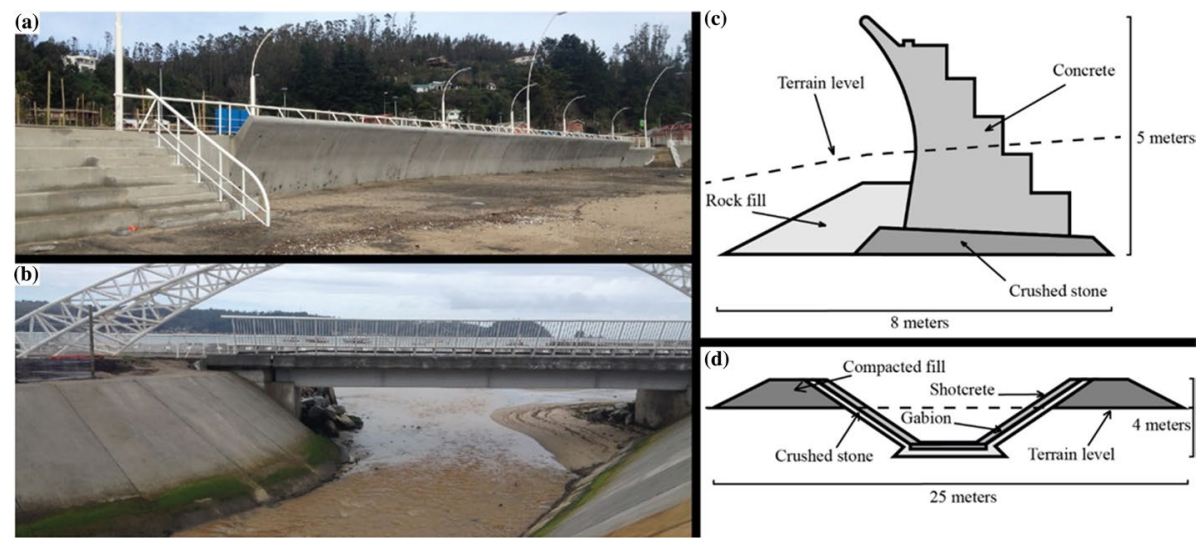

Fig. 8 a Wall and b channel built in Dichato after the 2010 event. c Detail of wall and channel (d) 
Table 5 Amount of material used for the construction of the wall in Litril Sector

\begin{tabular}{lcclll}
\hline Litril Sector & \multicolumn{5}{l}{} \\
\hline Profile & Length $(\mathrm{m})$ & $\mathrm{RC}\left(\mathrm{m}^{2}\right)$ & $\begin{array}{l}\text { Crushed stone } \\
\left(\mathrm{m}^{2}\right)\end{array}$ & $\begin{array}{l}\text { Layer compaction } \\
(\mathrm{m})\end{array}$ & Rock fill $\left(\mathrm{m}^{2}\right)$ \\
\hline A & 320.50 & 7.16 & 2.16 & 4.31 & 1.43 \\
B & 126.56 & 6.75 & 2.16 & 4.31 & 0.00 \\
C & 139.65 & 3.77 & 1.58 & 3.16 & 1.43 \\
D & 133.37 & 0.76 & 1.04 & 2.07 & 3.28 \\
E & 28.48 & 5.90 & 2.06 & 4.11 & 0.00 \\
Total & 748.56 & 24.33 & 8.98 & 17.96 & 6.13 \\
\hline
\end{tabular}

Table 6 Amount of material used for the construction of the wall in Etapa 1 Sector

\begin{tabular}{lccccc}
\hline Etapa 1 Sector & \multicolumn{5}{l}{} \\
\hline Profile & Length $(\mathrm{m})$ & $\mathrm{RC}\left(\mathrm{m}^{2}\right)$ & $\begin{array}{l}\text { Crushed stone } \\
\left(\mathrm{m}^{2}\right)\end{array}$ & $\begin{array}{l}\text { Layer compaction } \\
(\mathrm{m})\end{array}$ & Rock fill $\left(\mathrm{m}^{2}\right)$ \\
\hline A & 485.38 & 8.67 & 2.47 & 4.99 & 4.35 \\
B & 158.98 & 8.82 & 2.47 & 4.99 & 0.00 \\
C & 260.70 & 5.08 & 1.83 & 3.65 & 4.35 \\
D & 252.48 & 0.61 & 1.00 & 2.00 & 4.71 \\
E & 93.28 & 7.94 & 2.47 & 4.99 & 0.00 \\
Total & 1250.82 & 31.12 & 10.23 & 20.62 & 13.40 \\
\hline
\end{tabular}

Table 7 Amount of material used for the construction of the wall in Estero Sector

\begin{tabular}{lccccc}
\hline Estero Sector & \multicolumn{5}{l}{} \\
\hline Profile & Length $(\mathrm{m})$ & $\mathrm{RC}\left(\mathrm{m}^{2}\right)$ & $\begin{array}{l}\text { Crushed stone } \\
\left(\mathrm{m}^{2}\right)\end{array}$ & $\begin{array}{l}\text { Layer compaction } \\
(\mathrm{m})\end{array}$ & Rock fill $\left(\mathrm{m}^{2}\right)$ \\
\hline A & 193.80 & 8.99 & 2.47 & 4.89 & 3.20 \\
$\mathrm{~B}$ & 15.15 & 8.58 & 2.47 & 4.88 & 0.00 \\
$\mathrm{C}$ & 12.64 & 4.84 & 1.83 & 3.65 & 3.20 \\
$\mathrm{D}$ & 25.29 & 0.59 & 1.00 & 2.00 & 3.66 \\
$\mathrm{G}$ & 12.65 & 3.16 & 1.63 & 3.25 & 5.27 \\
$\mathrm{H}$ & 16.80 & 5.60 & 2.17 & 4.39 & 0.00 \\
$\mathrm{I}$ & 94.65 & 5.72 & 2.12 & 4.28 & 3.20 \\
Total & 370.98 & 37.48 & 13.67 & 27.34 & 18.51 \\
\hline
\end{tabular}

\section{Appendix 1.2: Channel}

In the case of the channel, there was one average profile used along the $286 \mathrm{~m}$ of its length. Thus, the material summary of it is shown in Table 8. 
Table 8 Amount of material used for the construction of the channel

\begin{tabular}{lllll}
\hline Channel & & & \\
\hline Length $(\mathrm{m})$ & Shotcrete $\left(\mathrm{m}^{2}\right)$ & Filling $\left(\mathrm{m}^{2}\right)$ & Layer compaction $(\mathrm{m})$ & Excavation $\left(\mathrm{m}^{2}\right)$ \\
\hline 286 & 5.18 & 17.12 & 9.85 & 18.22 \\
\hline
\end{tabular}

\section{Appendix 2: Selection of fragility curves}

The fragility curves used correspond to a work by Suppasri et al. (2012) where six levels of damage were defined as 1: minor damage, 2: moderate damage, 3: major damage, 4: complete damage, 5: collapse, and 6: washed away. All six levels were conceived for wood, masonry, reinforced concrete, and steel frames, as shown in Fig. 9.

(a)

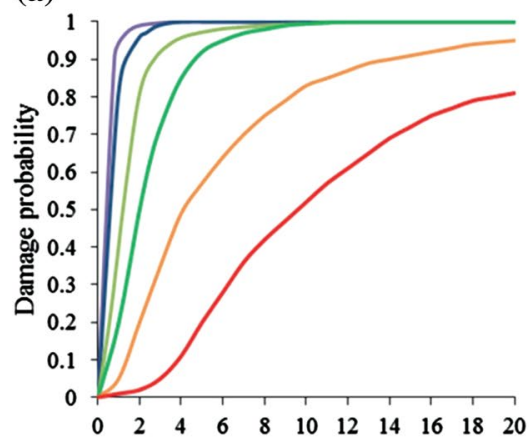

(c)

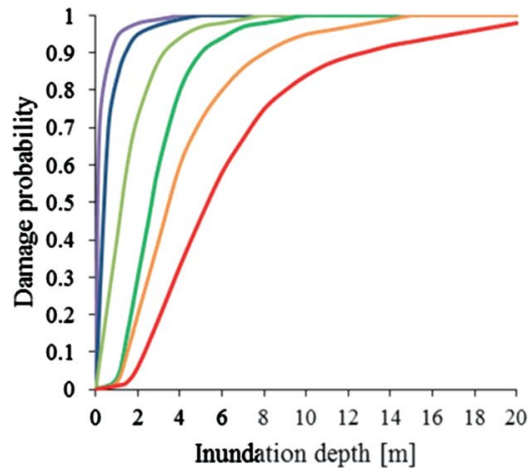

(b)

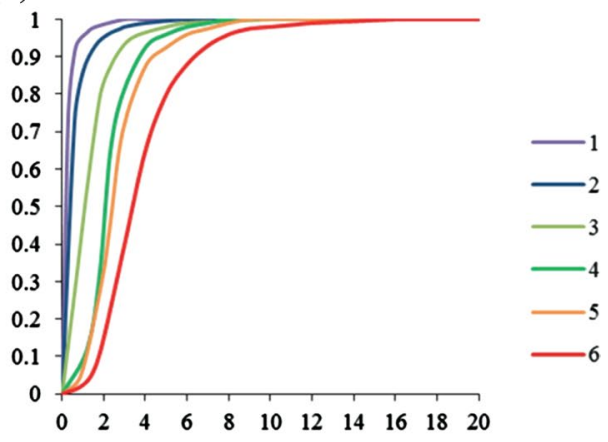

(d)

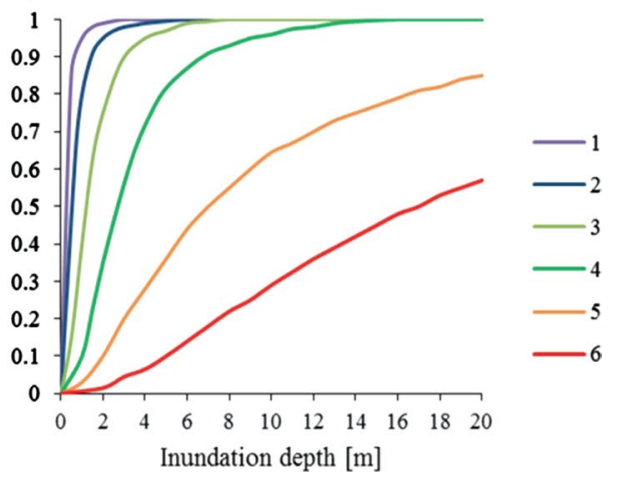

Fig. 9 Fragility curves for steel (a), wood (b), masonry (c) and RC (d), for levels 1 through 6, where 1 is minor damage, 2 is moderate damage, 3 is major damage, 4 is complete damage, 5 is collapse, and 6 is washed away (Suppasri et al. 2012) 


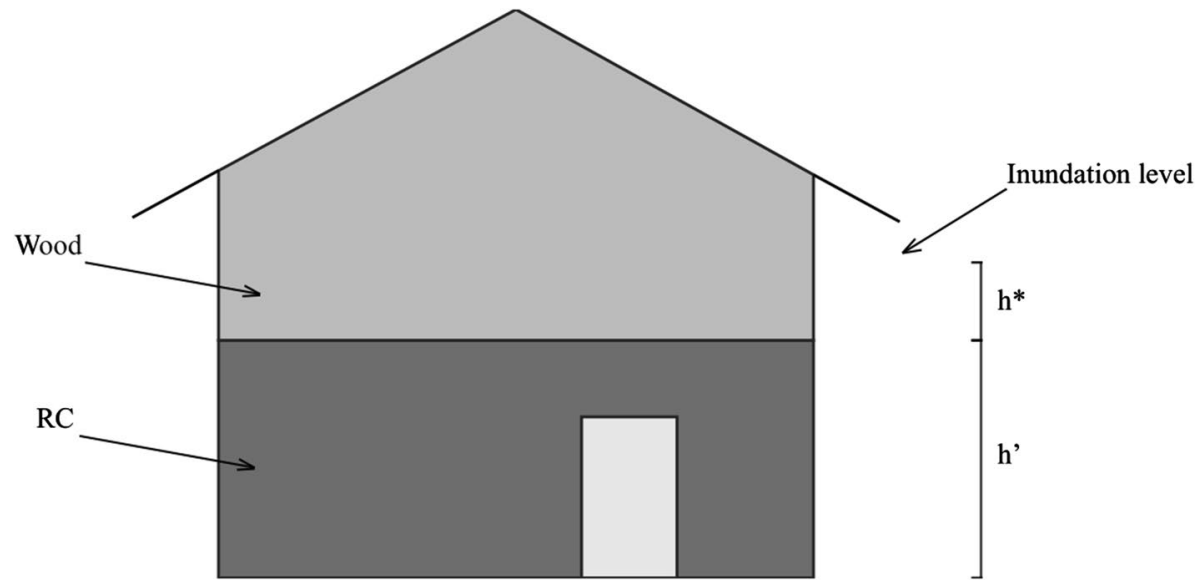

Fig. 10 Two-story house with mixed materiality

\section{Appendix 2.1: Fragility curve for mixed materials}

A fifth typology is proposed in the present investigation, which corresponds to a mix between reinforced concrete and wood for a specific kind of two-story houses. To this end, we consider the fragility curves for both reinforced concrete and wood, where the first story's materiality is reinforced concrete, while the second is made from wood. Thus, the idea is to apply an inundation height to each curve according to the relative (with respect of the base of each story) level of inundation of the first and the second stories. Therefore, using Fig. 10 as a reference, an inundation level equal to $h^{\prime}$ would be considered for the RC's fragility curve, and in the case of the wood's curve, an inundation height equal to $h^{*}$ is used. The final percentage of damage becomes the average between both curves.

For instance, if a house built with mixed materials is exposed to an inundation height of $2.5 \mathrm{~m}$, the total damage would be an average of the damage on the RC first story with an inundation of $h^{\prime}=2 \mathrm{~m}$ and the damage on the wooden second story with an inundation of $h^{*}=0.5 \mathrm{~m}$. The RC curve shows that with a $2 \mathrm{~m}$ inundation, the approximated damage probabilities are: $100 \%$ chance of minor damage, $95 \%$ chance of moderate damage, $80 \%$ chance of major damage, $40 \%$ chance of complete damage, $10 \%$ chance of collapse, and $0 \%$ of washed away. On the other hand, the wood curve shows that with a 0.5 m inundation, the approximated damage probabilities are $85 \%, 60 \%, 20 \%, 5 \%, 0 \%, 0 \%$, respectively. With these numbers, it is possible to apply the methodology explained in Sect. 3.2.3, with Eq. (2) and the information presented in Table 1.

\section{Appendix 3: Valuation of buildings}

All the information utilized for the valuation of the buildings' sample was obtained from the Servicio de Impuestos Internos (SII) and is presented in Table 9. The actual price of a building was considered to include the value of the terrain because of limitations in the available information. 


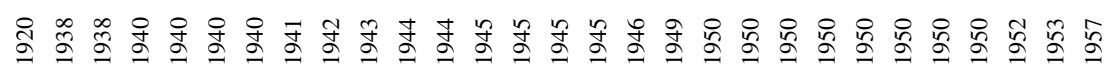

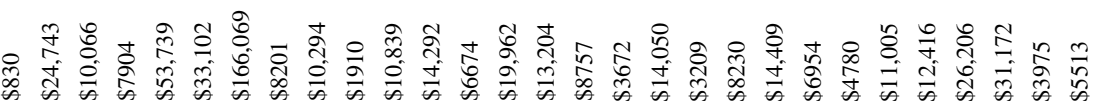

ถิ (1) 


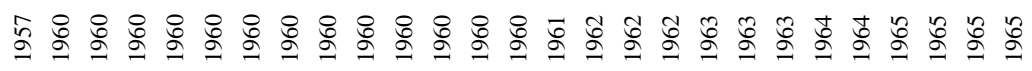

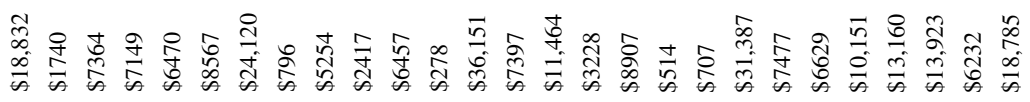

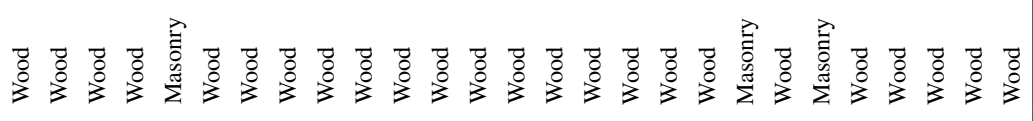

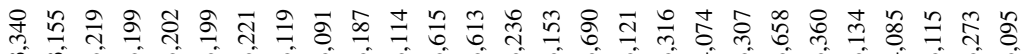

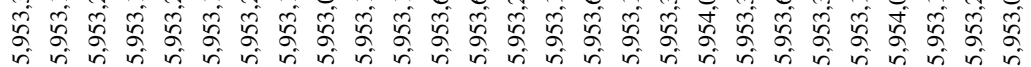




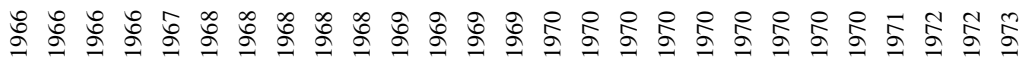

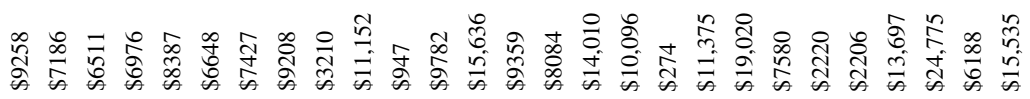

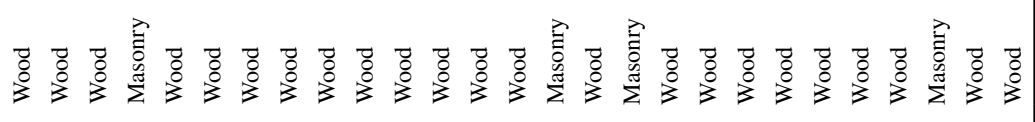

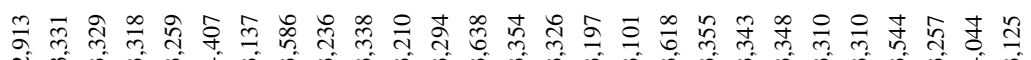

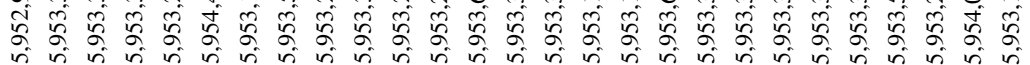




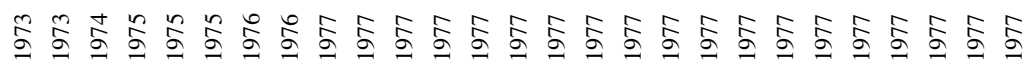

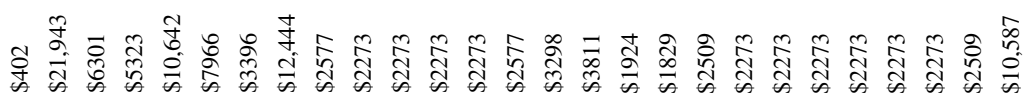

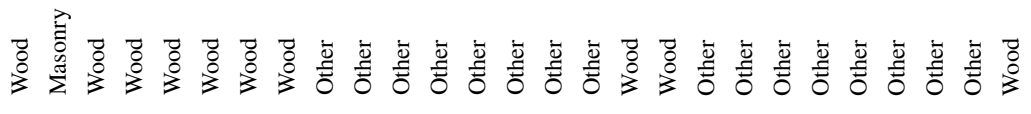

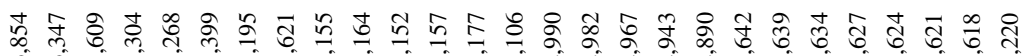

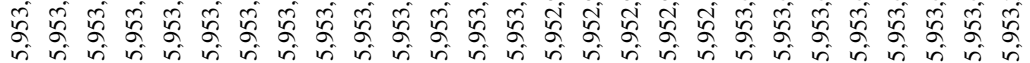




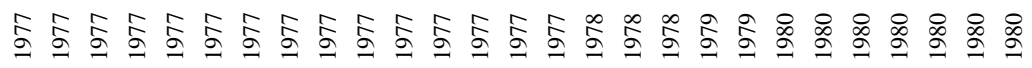

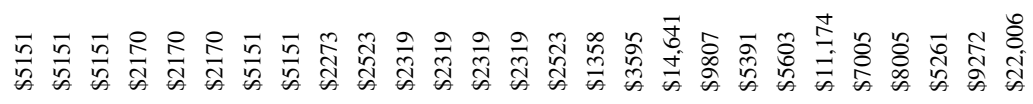

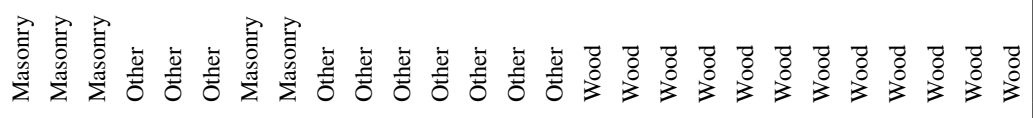

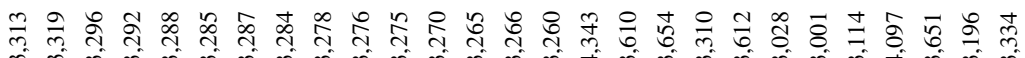

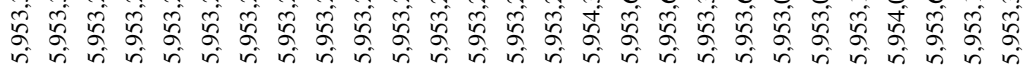




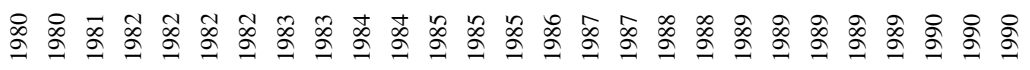

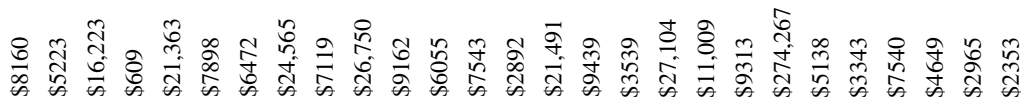

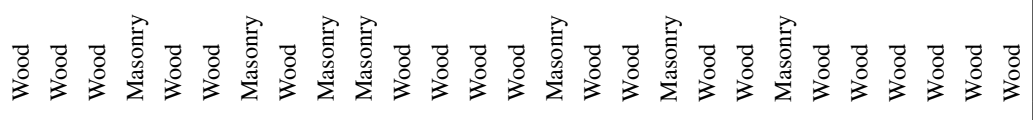

సै

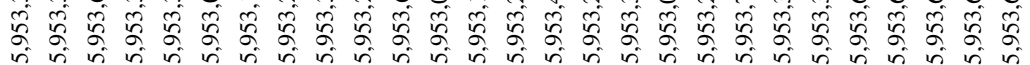




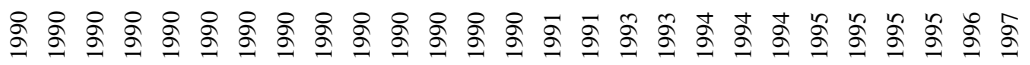

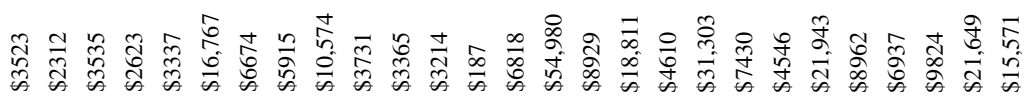

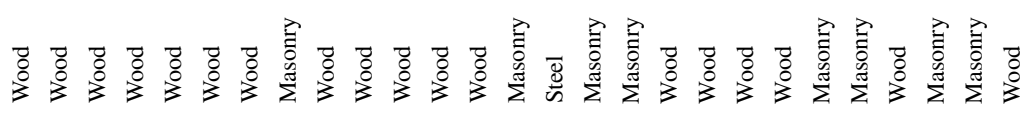

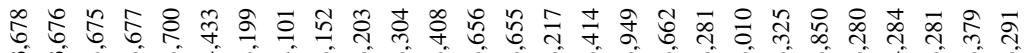

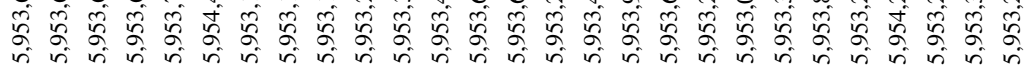
के हो की (1)

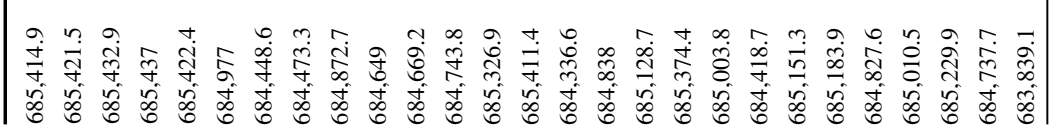




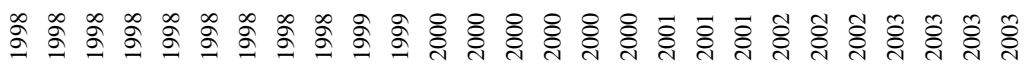

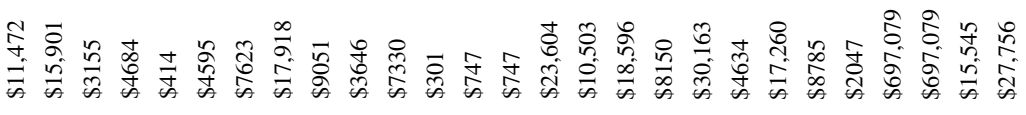

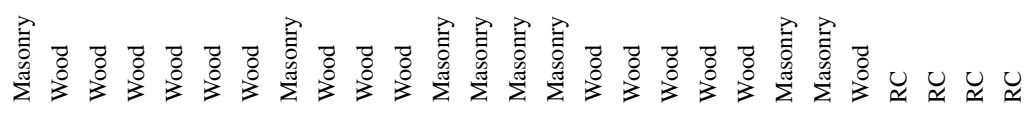

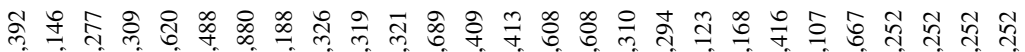

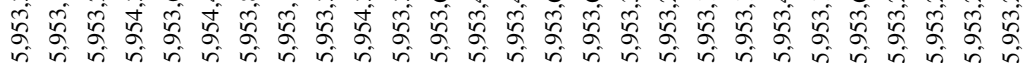

\section{$\mid$}

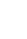




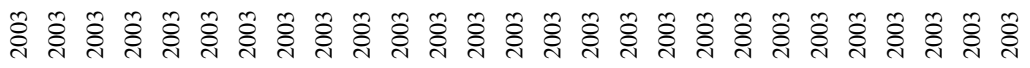

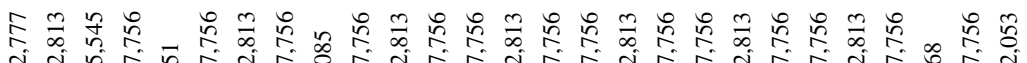

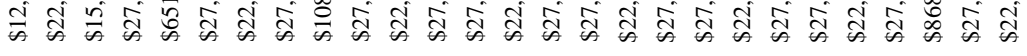

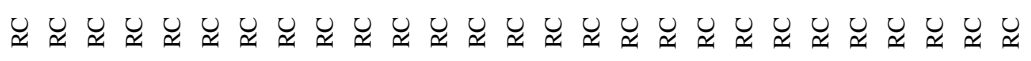

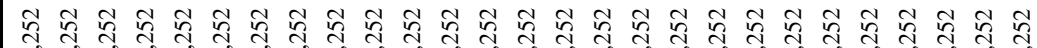

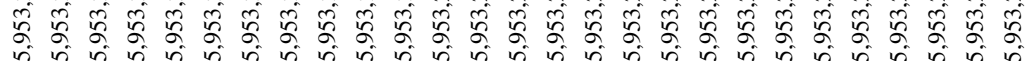

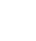




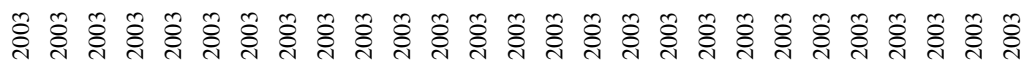

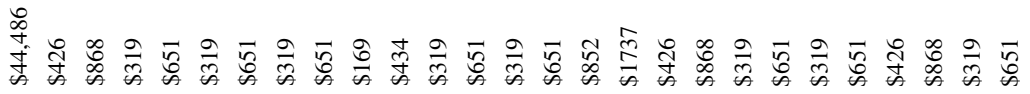

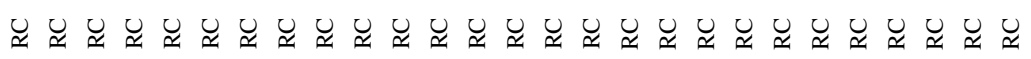

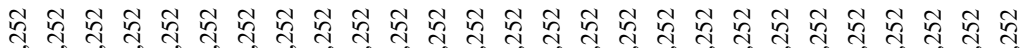

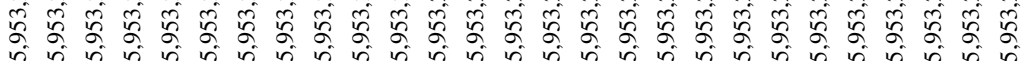




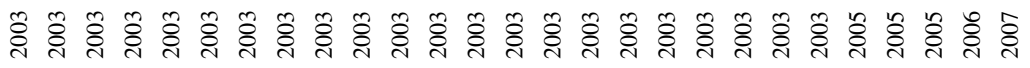

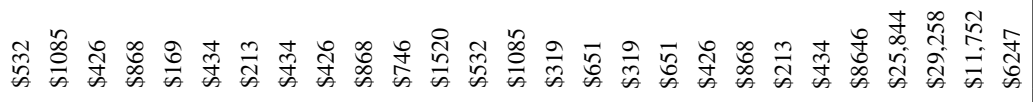

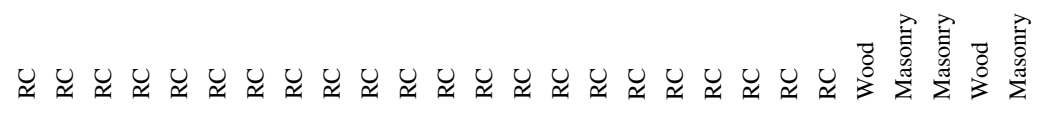

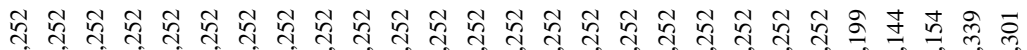

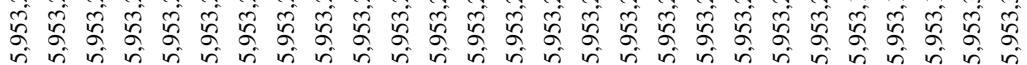

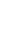




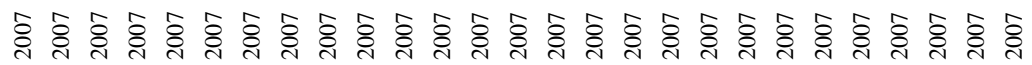

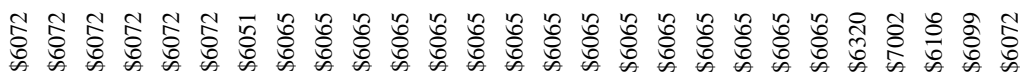

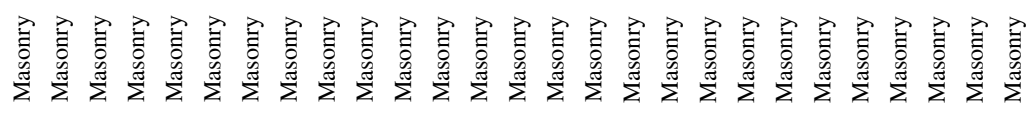

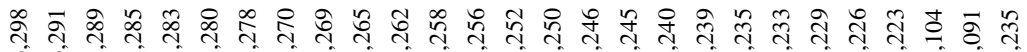

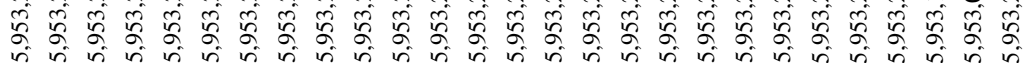


宅

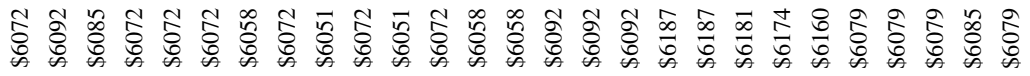

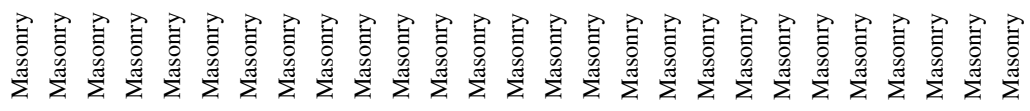

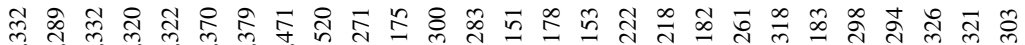

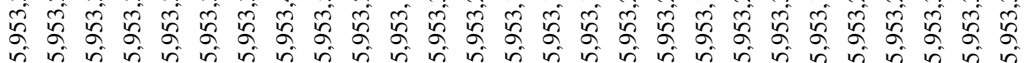




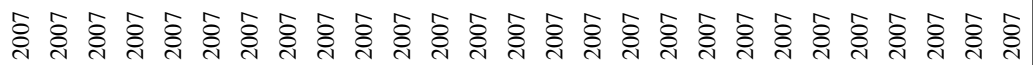

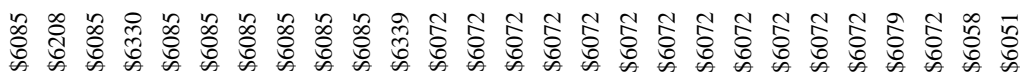

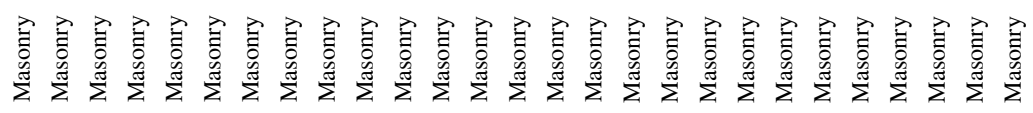

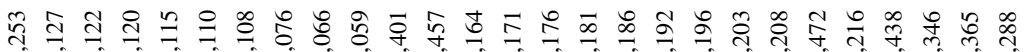

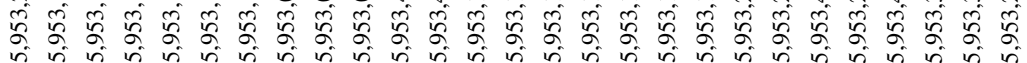


宅 实

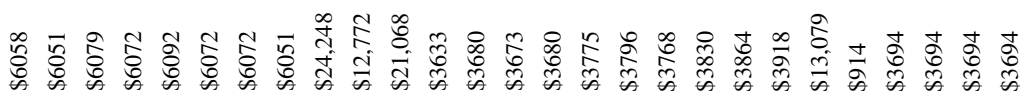

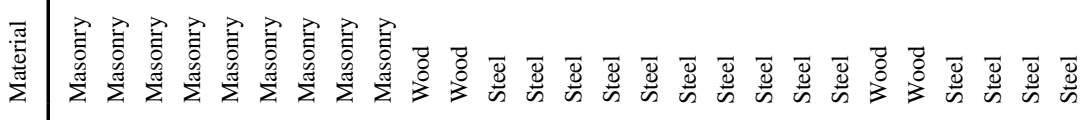

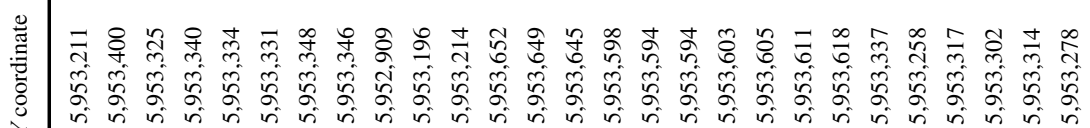




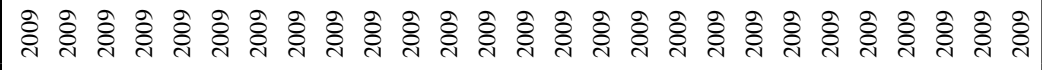

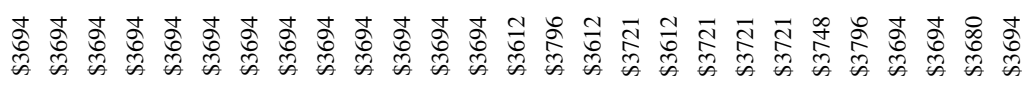

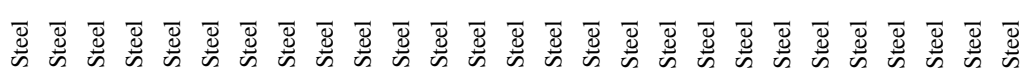

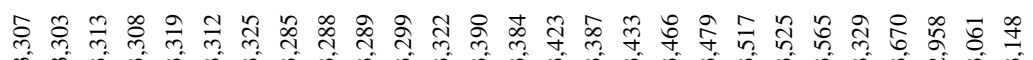

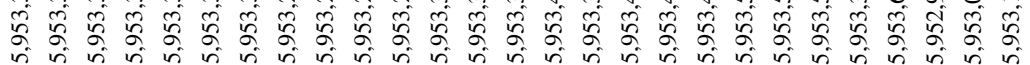




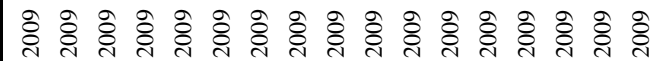

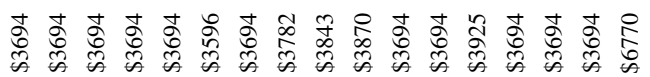

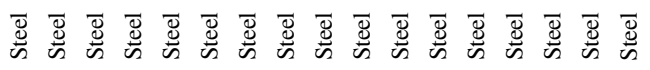

音

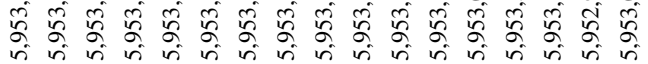




\section{References}

Adriano B, Mas E, Koshimura S et al (2014) Scenarios of earthquake and tsunami damage probability in Callao Region, Peru using tsunami fragility functions. J Disaster Res 9:968-975

Adriano B, Hayashi S, Gokon H et al (2016) Understanding the extreme tsunami inundation in Onagawa Town by the 2011 Tohoku Earthquake, its effects in urban structures and coastal facilities. Coast Eng J 58:1640013. https://doi.org/10.1142/S0578563416400131

Aida I (1978) Reliability of a tsunami source model derived from fault parameters. J Phys Earth 26:57-73. https://doi.org/10.4294/jpe1952.26.57

Aránguiz R, González G, González J et al (2016) The 16 September 2015 Chile tsunami from the posttsunami survey and numerical modeling perspectives. Pure Appl Geophys 173:333-348. https://doi. org/10.1007/s00024-015-1225-4

Araya P (2007) Catálogo actualizado de intensidades sísmicas para Chile. Universidad de Chile, Santiago

Arcas D, Titov V (2006) Sumatra tsunami: lessons from modeling. Surv Geophys 27:679-705. https://doi. org/10.1007/s10712-006-9012-5

Arcos MEM, LeVeque RJ (2015) Validating velocities in the GeoClaw tsunami model using observations near Hawaii from the 2011 Tohoku Tsunami. Pure Appl Geophys 172:849-867. https://doi. org/10.1007/s00024-014-0980-y

Cançado V, Brasil L, Nascimento N, Guerra A (2008) Flood risk assessment in an urban area : measuring hazard and vulnerability. In: 11th international conference on urban damage, Edinburgh, Scotland, UK, pp $1-10$

Catalán PA, Aránguiz R, González G et al (2015) The 1 April 2014 Pisagua Tsunami: observations and modeling. Geophys Res Lett. https://doi.org/10.1002/2015GL063333

Centro Sismológico Nacional (2013) Sismicidad y terremotos en Chile

Cutter SL, Mitchell JT, Scott MS (2000) Revealing the vulnerability of people and places: a case study of Georgetown County, South Carolina. Ann As Am Geogr 90:713-737. https://doi. org/10.1111/0004-5608.00219

Cutter SL, Boruff BJ, Shirley WL (2003) Social vulnerability to environmental hazards. Soc Sci Q 84:242261. https://doi.org/10.1111/1540-6237.8402002

De Risi R, Goda K, Yasuda T, Mori N (2017) Is flow velocity important in tsunami empirical fragility modeling? Earth-Sci Rev 166:64-82. https://doi.org/10.1016/j.earscirev.2016.12.015

Delouis B, Nocquet JM, Vallée M (2010) Slip distribution of the February 27, 2010 Mw=8.8 Maule Earthquake, central Chile, from static and high-rate GPS, InSAR, and broadband teleseismic data. Geophys Res Lett 37:1-7. https://doi.org/10.1029/2010GL043899

Favier P, Bertrand D, Eckert N, Naaim M (2014a) A reliability assessment of physical vulnerability of reinforced concrete walls loaded by snow avalanches. Nat Hazards Earth Syst Sci 14:689-704. https://doi. org/10.5194/nhess-14-689-2014

Favier P, Eckert N, Bertrand D, Naaim M (2014b) Sensitivity of avalanche risk to vulnerability relations. Cold Reg Sci Technol 108:163-177. https://doi.org/10.1016/j.coldregions.2014.08.009

Fritz HM, Petroff CM, Catalán PA et al (2011) Field Survey of the 27 February 2010 Chile Tsunami. Pure Appl Geophys 168:1989-2010. https://doi.org/10.1007/s00024-011-0283-5

Gobierno Regional del Bío-Bío (2010) Plan de reconstrucción del borde costero-PRBC18

Goda K, Li S, Mori N, Yasuda T (2015) Probabilistic tsunami damage assessment considering stochastic source models: application to the 2011 Tohoku Earthquake. Coast Eng J 57:1-38. https://doi. org/10.1142/S0578563415500151

González FI, Geist EL, Jaffe B et al (2009) Probabilistic tsunami hazard assessment at Seaside, Oregon, for near-and far-field seismic sources. J Geophys Res Ocean 114:1-19. https://doi.org/10.1029/2008J C005132

Herrmann Lunecke MG (2015) Urban planning and tsunami impact mitigation in Chile after February 27, 2010. Nat Hazards 79:1591-1620

Imamura F, Fujima K, Arikawa T (2010) Field survey of the 2010 Chilean tsunami

Imamura F, Muhari A, Mas E et al (2012) Tsunami disaster mitigation by integrating comprehensive countermeasures in Padang City, Indonesia. J Disaster Res 7:48-64

Instituto Nacional de Estadísticas. http://www.ine.cl/. Accessed 4 Jan 2017

Iwata K, Ito Y, Managi S (2014) Public and private mitigation for natural disasters in Japan. Int J Disaster Risk Reduct 7:39-50. https://doi.org/10.1016/j.ijdrr.2013.12.005

Khew YTJ, Jarzebski MP, Dyah F et al (2015) Assessment of social perception on the contribution of hard-infrastructure for tsunami mitigation to coastal community resilience after the 2010 Tsunami: greater Concepcion area, Chile. Int J Disaster Risk Reduct 13:324-333. https://doi.org/10.1016/j.ijdrr .2015 .07 .013 
Koshimura S, Namegaya Y, Yanagisawa H (2009a) Tsunami fragility: a new measure to identify tsunami damage. J Disaster Res 4:479-488

Koshimura S, Oie T, Yanagisawa H et al (2009b) Developing fragility functions for tsunami damage estimation using numerical model and post-tsunami data from Banda Aceh, Indonesia. Coast Eng J 51:243273. https://doi.org/10.1142/S0578563409002004

Koshimura S, Matsuoka M, Matsuyama M et al (2010) Field survey of the 2010 tsunami in Chile

León J, Mokrani C, Catalán P et al (2019) The role of built environment's physical urban form in supporting rapid tsunami evacuations: using computer-based models and real-world data as examination tools. Front Built Environ 4:1-15. https://doi.org/10.3389/fbuil.2018.00089

Lomnitz C (1970) Major earthquakes and tsunamis in Chile during the period 1535 to 1955 . Int J Earth Sci 59:938-960

Macabuag J, Rossetto T, Ioannou I et al (2016) A proposed methodology for deriving tsunami fragility functions for buildings using optimum intensity measures. Nat Hazards. https://doi.org/10.1007/s1106 9-016-2485-8

MacInnes BT, Gusman AR, LeVeque RJ, Tanioka Y (2013) Comparison of earthquake source models for the 2011 Tohoku Event using tsunami simulations and near-field observations. Bull Seismol Soc Am 103:1256-1274. https://doi.org/10.1785/0120120121

Martínez C, Rojas O, Villagra P et al (2016) Risk factors and perceived restoration in a town destroyed by the 2010 Chile Tsunami. Nat Hazards Earth Syst Sci Discuss. https://doi.org/10.5194/nhess-2016-256

Mas E, Koshimura S, Suppasri A et al (2012) Developing tsunami fragility curves using remote sensing and survey data of the 2010 Chilean Tsunami in Dichato. Nat Hazards Earth Syst Sci 12:2689-2697. https ://doi.org/10.5194/nhess-12-2689-2012

Matsutomi H, Harada K, Ogasawara T, Kataoka S (2010) Preliminary field survey report of the 2010 Chile Earthquake Tsunami

Melgar D, Bock Y (2013) Near-field tsunami models with rapid earthquake source inversions from landand ocean-based observations: the potential for forecast and warning. J Geophys Res Solid Earth 118:5939-5955. https://doi.org/10.1002/2013JB010506

Mikami T, Shibayama T, Takewaka S et al (2011) Field survey of tsunami disasters in Chile 2010. J Japan Soc Civ Eng 67:529-534

Ministerio de Desarrollo Social (2013) Metodología de preparación y evaluación de proyectos de evacuación y drenaje de aguas lluvias

Montenegro-Romero T, Peña-Cortés F (2010) Gestión de la emergencia ante eventos de inundación por tsunami en Chile: El caso de Puerto Saavedra. Rev Geogr Norte Gd 80:63-80. https://doi.org/10.4067/ S0718-34022010000300004

Nahuelpan López E, Varas Insunza J (2010) El Terremoto/Tsunami en Chile: Una mirada a las estadísticas médico legales

Nandasena NAK, Sasaki Y, Tanaka N (2012) Modeling field observations of the 2011 Great East Japan tsunami: efficacy of artificial and natural structures on tsunami mitigation. Coast Eng 67:1-13. https://doi. org/10.1016/j.coastaleng.2012.03.009

Okada Y (1985) Surface deformation due to shear and tensile faults in a half-space. Bull Seismol Soc Am 75:1135-1154

Ozer Sozdinler C, Yalciner AC, Zaytsev A et al (2015) Investigation of hydrodynamic parameters and the effects of breakwaters during the 2011 Great East Japan Tsunami in Kamaishi Bay. Pure Appl Geophys 172:3473-3491. https://doi.org/10.1007/s00024-015-1051-8

Park H, Cox DT (2016) Probabilistic assessment of near-field tsunami hazards: inundation depth, velocity, momentum flux, arrival time, and duration applied to Seaside, Oregon. Coast Eng 117:79-96. https:// doi.org/10.1016/j.coastaleng.2016.07.011

Pelling M, Maskrey A, Ruiz P, Hall L (2004) Reducing disaster risk. a challenge for development. United Nations Development Programme, New York

Penning-Rowsell E, Johnson C, Tunstall S et al (2005) The benefits of flood and coastal risk management: a manual of assessment techniques. Middlesex University PRess, London

Portal Ondac Construcción. http://www.ondac.cl/. Accessed 1 Aug 2016

Pulido N, Sekiguchi T, Shoji G et al (2010) Earthquake source process and strong ground motions of the 2010 Chile mega-earthquake

Robertson I, Chock G, Morla J (2012) Structural analysis of selected failures caused by the 27 February 2010 Chile Tsunami. Earthq Spectra 28:215-243. https://doi.org/10.1193/1.4000035

Saito T, Kono S, Kusunoki K, et al (2010) Building damage investigation of the 2010 Chile Earthquake and Tsunami disaster

Santa María H, Hube MA, Rivera F et al (2016) Development of national and local exposure models of residential structures in Chile. Nat Hazards. https://doi.org/10.1007/s11069-016-2518-3 
Shimozono T, Sato S (2016) Coastal vulnerability analysis during tsunami-induced levee overflow and breaching by a high-resolution flood model. Coast Eng 107:116-126. https://doi.org/10.1016/j.coast aleng.2015.10.007

Shuto N (1991) Numerical simulation of tsunamis-its present and near future. Nat Hazards 4:171-191

Siembieda W, Johnson L, Franco G (2012) Rebuild fast but rebuild better: Chile's initial recovery following the 27 February 2010 earthquake and tsunami. Earthq Spectra 28:S621-S641

Suppasri A, Koshimura S, Imamura F (2011) Developing tsunami fragility curves based on the satellite remote sensing and the numerical modeling of the 2004 Indian Ocean tsunami in Thailand. Nat Hazards Earth Syst Sci 11:173-189. https://doi.org/10.5194/nhess-11-173-2011

Suppasri A, Mas E, Charvet I et al (2012) Building damage characteristics based on surveyed data and fragility curves of the 2011 Great East Japan tsunami. Nat Hazards 66:319-341. https://doi.org/10.1007/ s11069-012-0487-8

Suppasri A, Shuto N, Imamura F et al (2013) Lessons Learned from the 2011 Great East Japan tsunami: performance of tsunami countermeasures, coastal buildings, and tsunami evacuation in Japan. Pure Appl Geophys 170:993-1018. https://doi.org/10.1007/s00024-012-0511-7

Tsunami Evaluation Subcommittee, Nuclear Civil Engineering Committee (2002) Tsunami assessment method for nuclear power plants in Japan

Urra Espinoza LI (2015) Estimación de daños por tsunami en Iquique. Universidad Católica de la Santísima Concepción

Venegas San Martín JF (2012) Análisis de vulnerabilidad por tsunami en la localidad de dichato, Región del Biobío - Chile. Universidad de Concepción, Concepción

Weichselgartner J (2001) Disaster mitigation: the concept of vulnerability revisited. Disaster Prev Manag 10:85-95. https://doi.org/10.1108/09653560110388609

Xu W (2017) Finite-fault slip model of the 2016 Mw 7.5 Chiloé earthquake, southern Chile, estimated from Sentinel-1 data. Geophys Res Lett 44:4774-4780

Servicio de Impuestos Internos

Yamazaki Y, Cheung KF (2011) Shelf resonance and impact of near-field tsunami generated by the 2010 Chile earthquake. Geophys Res Lett. https://doi.org/10.1029/2011GL047508

Yamazaki F, Maruyama Y, Miura H et al (2010) Development of spatial information database of building damage and tsunami inundation areas following the 2010 Chile Earthquake

Publisher's Note Springer Nature remains neutral with regard to jurisdictional claims in published maps and institutional affiliations. 